Review

\title{
Non-Conventional Tools to Preserve and Prolong the Quality of Minimally-Processed Fruits and Vegetables
}

\section{Maria Rosaria Corbo *, Daniela Campaniello, Barbara Speranza, Antonio Bevilacqua and Milena Sinigaglia}

Department of the Science of Agriculture, Food and Environment, University of Foggia, Via Napoli, 25, 71122 Foggia FG, Italy; E-Mails: daniela.campaniello@unifg.it (D.C.); barbara.speranza@unifg.it (B.S.); antonio.bevilacqua@unifg.it (A.B.); milena.sinigaglia@unifg.it (M.S.)

* Author to whom correspondence should be addressed; E-Mail: mariarosaria.corbo@unifg.it; Tel.: +39-881-589-232.

Academic Editor: Stefano Farris

Received: 7 October 2015 / Accepted: 20 November 2015 / Published: 26 November 2015

\begin{abstract}
The main topic of this paper is a focus on some non-conventional tools to preserve the microbiological and physico-chemical quality of fresh-cut fruits and vegetables. The quality of fresh-cut foods is the result of a complex equilibrium involving surface microbiota, storage temperature, gas in the headspace and the use of antimicrobials. This paper proposes a short overview of some non-conventional approaches able to preserve the quality of this kind of product, with a special focus on some new ways, as follows: (1) use of edible or antimicrobial-containing coatings (e.g., chitosan-based coatings) on fruits or vegetables; (2) alternative modified atmospheres (e.g., high $\mathrm{O}_{2}$-modified atmosphere packaging (MAP)) or the use of essential oils in the headspace; (3) conditioning solutions with antimicrobials or natural compounds for fruit salad; and (4) biopreservation and use of a probiotic coating.
\end{abstract}

Keywords: fresh-cut; conditioning liquid; coatings; spoiling microorganisms; probiotics

\section{Introduction}

In recent years the attention towards a healthy diet is considerably growing; the consumer is paying more attention to the importance of the freshness and healthiness of foods. Consumption of fruits and vegetables is considered a successful way to contrast the current tendency toward obesity (especially in 
children). It is known that fruits and vegetables contain essential nutrients and are the major source of various antioxidants (vitamin $\mathrm{C}$, vitamin $\mathrm{E}$ and $\beta$-carotene) that are necessary for the health, growth and development of the children. The World Health Organization (WHO), Food and Agriculture Organization (FAO), United States Department of Agriculture (USDA) and European Food Safety Authority (EFSA) recommended an increase of fruit and vegetable consumption to decrease the risk of cardiovascular diseases, cancer and ageing [1].

In addition, the consumer profile is changing as an effect of a stressed lifestyle: the number of working women and singles is gradually increasing; they are short on time and demand minimally-processed foods (also called ready-to-use) to save time on food preparation. To meet the consumer needs, the products should have an adequate shelf-life; it should be at least 4-7 days or even 21 days, depending on the products.

The International Fresh-cut Produce Association (IFPA) defines fresh-cut products as fruits or vegetables that have been trimmed and/or peeled and/or cut into a $100 \%$ usable product that is bagged or pre-packaged to offer consumers high nutrition, convenience and flavor, while still maintaining its freshness [2]. However, it is known that the processing of fruits and vegetables promotes physiological deterioration, biochemical changes and microbial degradation, beginning with raw materials, through processing methods and ending with packaging factors that affect the quality and shelf-life. These changes are due to tissue wounding, which includes browning, weight loss, accelerated respiration rate, off-flavor development, texture breakdown and increased susceptibility to microbial spoilage [3].

Thus, the search for new inexpensive and effective methods (such as chemical-based washing treatments, physical treatments, hurdle technology and packaging requirements) able to minimize these negative effects is of great interest to all of the stakeholders involved in the production and distribution of fresh fruits and vegetables.

The aim of this paper is to give insight into some non-conventional approaches able to ensure the microbiological stability and quality of minimally-processed fruits and vegetables with a special focus on some new ways currently available: (1) the use of edible or antimicrobial containing coatings (e.g., chitosan-based coatings) on fruits or vegetables; (2) alternative modified atmospheres (e.g., high $\mathrm{O}_{2}$-modified atmosphere packaging (MAP)) or the use of essential oils in the headspace; (3) conditioning solutions with antimicrobials or natural compounds for fruit-salad; and (4) biopreservation and the use of probiotic coatings.

\section{Use of Edible or Antimicrobial-Containing Coatings (e.g., Chitosan-Based Coatings) on Fruits or Vegetables}

Edible coatings (ECs) and edible films belong to the modern food protection system; over the past few years, interest in the use of edible coatings for perishable foods has considerably increased due to their advantages and potential applications [4]. Edible coatings and edible films are terms that are often used interchangeably; however, a distinction is necessary.

An edible coating is defined as a thin layer of edible material applied to the surface of foods in addition to or as a substitution for natural protective coatings, able to form a barrier to moisture, oxygen and solute movement for the food [5-10]. 
On the other hand, edible film is defined as a thin layer of edible material formed on a product surface as a coating or placed (pre-formed) on or between food components [11].

Thus, an edible film is a thin skin, which has been pre-formed (for example, by casting a biopolymer solution separately from the food to form a film later applied to the food), whilst an edible coating is a suspension or an emulsion, which is applied directly to the food surface and later forms a film [12].

Edible coatings and films do not replace traditional packaging materials, but provide an additional factor to be applied for food preservation; ECs are consumed along with the food, thus the composition must conform to the regulations applied to the food product.

One of the advantages in using edible coatings and films is the reduction of water loss, considered one of the main factors in the deterioration of perishable foods. In fact, this thin layer protects fruits and/or vegetables against moisture loss, maintaining the texture and extending the shelf-life of the product, forming a protective barrier. On the other hand, when edible coatings are poor in water vapor barrier properties, a weight or moisture loss of the product could be recovered.

Numerous benefits result when edible coatings are applied, and these are summarized in Figure 1.

In addition, edible coatings may enhance sensory characteristics, can be consumed along with the food, provide additional nutrients and include quality-enhancing antimicrobials. Furthermore, they may reduce the cost and also the amount of traditional packaging used [13].

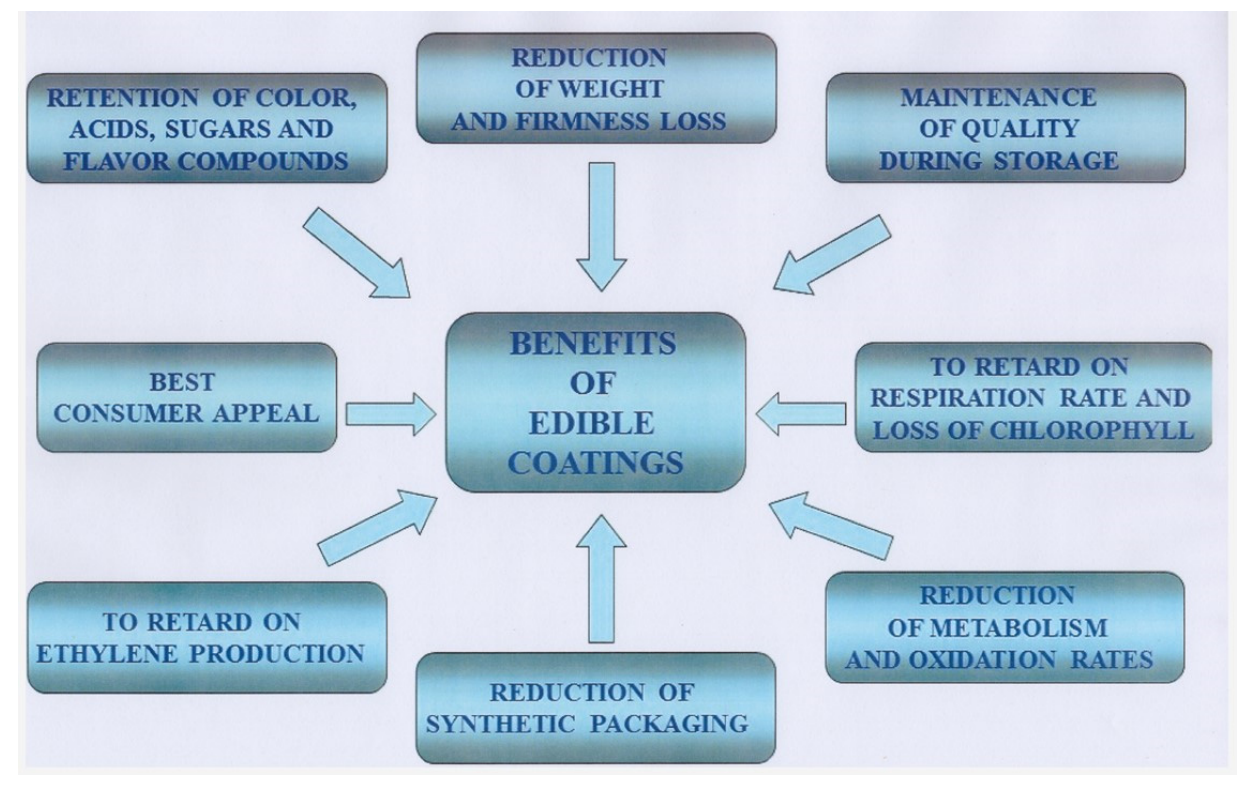

Figure 1. Main benefits of edible coatings.

\subsection{Edible Coating Materials}

Numerous varieties of fruits and vegetables are characterized by cuticle, a natural waxy layer on the surface, which, generally, has a low permeability to water vapor. To enhance the barrier properties of cuticle and/or substitute it when processing operations remove it, edible coatings could be applied.

Water and ethanol (or a blend of these compounds) are the solvents generally used for edible coating production.

Various coating materials could be added, but it is necessary that they possess some specific requirements (water solubility, hydrophobic of hydrophilic nature, easy formation of coatings, good 
sensorial properties) to obtain the resulting coating. In addition, an essential requirement is the plasticizing capacity to provide films with good flexibility properties; for this purpose, glycerol is generally used, followed by sorbitol, polyethylene glycol (PEG) and sugars [13].

Hydrocolloids have a good aptitude for forming continuous and cohesive matrices thanks to the hydrogen bonding of their polymeric chains.

Polysaccharides, proteins and lipids, alone or in combination, can also be used to produce edible films and coating. Lipids (together with waxes and fatty acids) do not have a suitable stand-alone filmmaking nature; they are usually opaque and relatively inflexible; the resulting films could also be quite fragile and unstable (rancidity) [9]. For this reason, lipids are generally incorporated into hydrocolloids-based films formulations [13].

The main polysaccharide, protein and lipid compounds used in edible coatings are reported in Table 1.

Table 1. Main polysaccharides, proteins and lipid compounds used for edible coatings.

\begin{tabular}{|c|c|}
\hline $\begin{array}{c}\text { Main } \\
\text { Component }\end{array}$ & Description \\
\hline \multirow[b]{4}{*}{ Polysaccharides } & $\begin{array}{l}\text { Starch contains amylose }((1 \rightarrow 4) \text { - } \alpha \text {-D-glucopyranosyl) and amylopectin (amylose branched with side } \\
\text { units of D-glucopyranosyl linked by } \alpha-1,6 \text {-glycosidic bonds). Amylose has a film-forming ability, } \\
\text { rendering strong, isotropic, odorless, tasteless and colorless films. It is inexpensive, widely available } \\
\text { and easy to handle. Due to its good oxygen barrier, starch is used for coating fruits and vegetables } \\
\text { characterized by high respiration rates, thus suppressing respiration and retarding the oxidation of the } \\
\text { coated products. }\end{array}$ \\
\hline & $\begin{array}{l}\text { Dextrins derive from starch and are characterized by a smaller molecular size. Coatings resulting from } \\
\text { dextrins provide a better water vapor resistance than starch coatings [14]. }\end{array}$ \\
\hline & $\begin{array}{l}\text { Pullulan derives from starch and is edible and biodegradable; relative films are transparent, elastic, } \\
\text { odorless and tasteless [15]. Pullulan-based coatings have shown potential for preserving fresh } \\
\text { strawberries and kiwifruits because of their barriers to moisture, } \mathrm{O}_{2} \text { and } \mathrm{CO}_{2}[16] \text {. Pullulan films } \\
\text { themselves do not demonstrate antimicrobial activity [17]. }\end{array}$ \\
\hline & 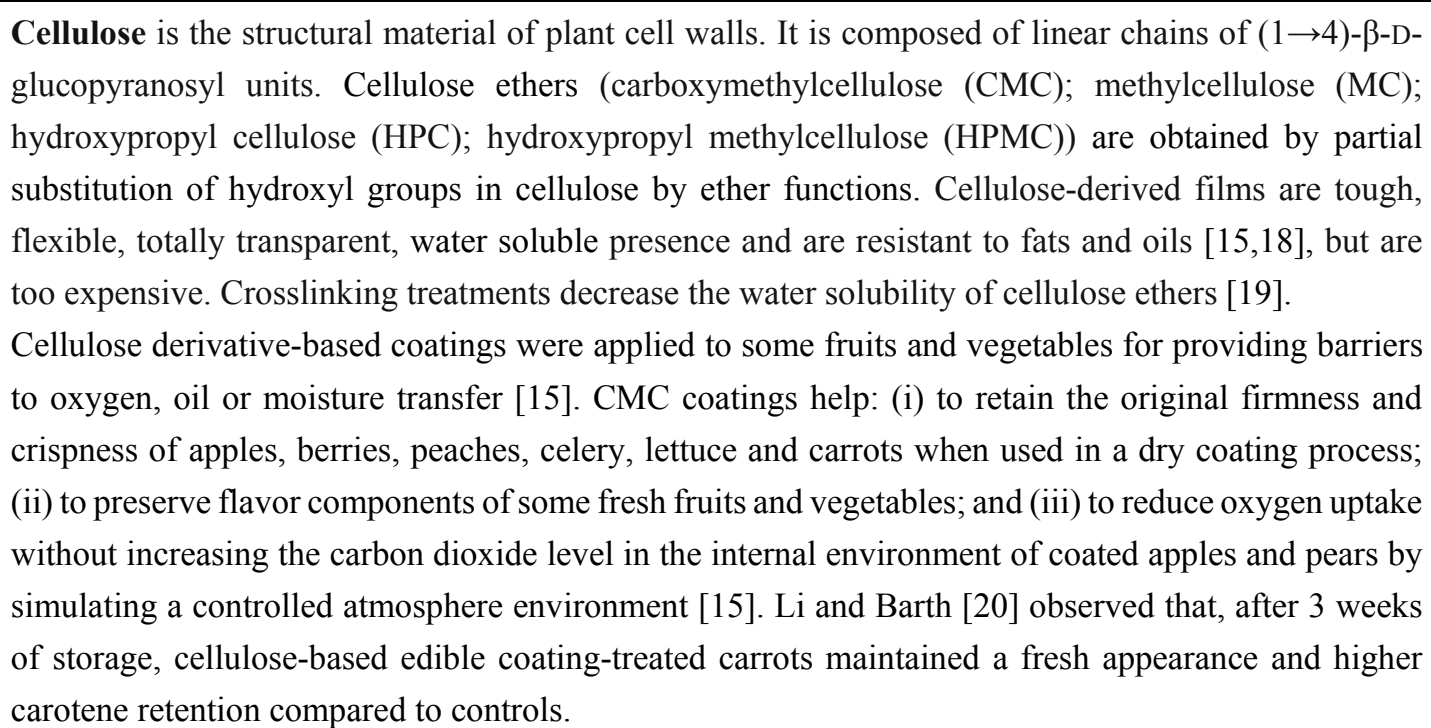 \\
\hline
\end{tabular}


Table 1. Cont.

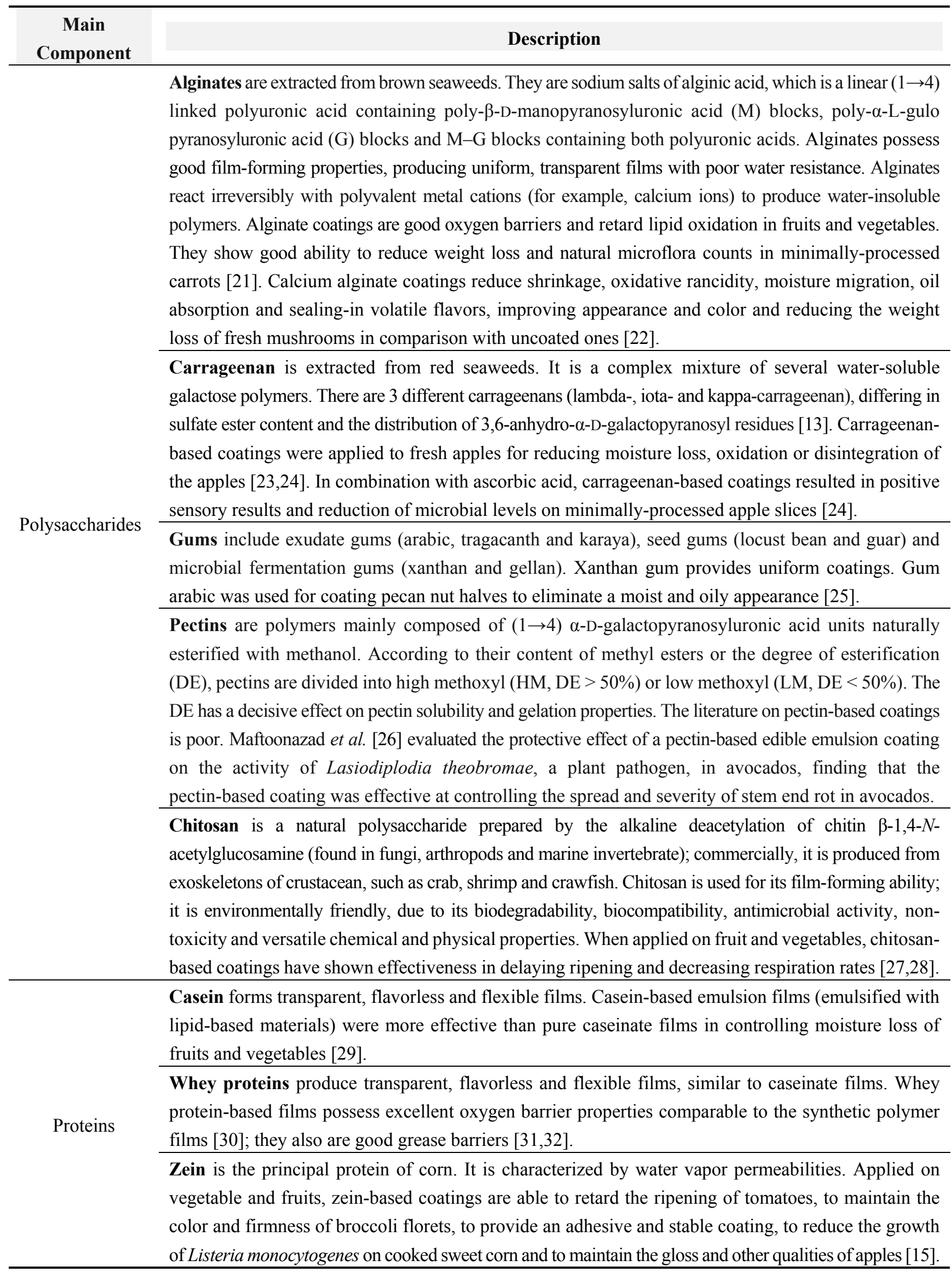


Table 1. Cont.

\begin{tabular}{|c|c|}
\hline $\begin{array}{c}\text { Main } \\
\text { Component }\end{array}$ & Description \\
\hline Proteins & $\begin{array}{l}\text { Soy proteins (SP) are extracted from defatted protein meal. Soy protein coatings generally have poor } \\
\text { moisture resistance and water vapor barrier properties due to the inherent hydrophilicity of the protein and } \\
\text { the addition of hydrophilic plasticizers; whilst they are potent oxygen barriers. SP coatings are used to } \\
\text { preserve the freshness of apple slices and/or to retard the senescence process of kiwifruit [15]. }\end{array}$ \\
\hline \multirow{3}{*}{ Lipids } & $\begin{array}{l}\text { Most fatty acids derived from vegetable oils are considered GRAS (generally recognized as safe). } \\
\text { Lipid-based coatings are compatible with other coating-forming agents; in addition, they have high } \\
\text { water vapor and gas barrier properties. However, lipid-based coatings present a greasy surface and } \\
\text { undesirable organoleptic properties, such as waxy taste and lipid rancidity [33]. Finally, some lipid } \\
\text { materials are unstable when subjected to temperature changes. }\end{array}$ \\
\hline & $\begin{array}{l}\text { Waxes (carnauba wax, beeswax, paraffin wax and others) have been used as protective coatings for } \\
\text { blocking moisture transport, reducing surface abrasion during fruit handling, controlling the browning } \\
\text { of the skin in fruits by improving mechanical integrity and controlling the internal gas composition of } \\
\text { the fruits. Wax coatings are applied on fruits (citrus, apples, cucumbers) and vegetables (tomatoes, } \\
\text { asparagus, beans, beets, carrots, celery, eggplant, peppers, potatoes, radishes, squash and turnips. }\end{array}$ \\
\hline & $\begin{array}{l}\text { Resin coatings are effective at reducing water loss, but are the least permeable to gases; thus, fruit can } \\
\text { suffer undesirable changes, such as anaerobic respiration and flavor changes. }\end{array}$ \\
\hline
\end{tabular}

Polysaccharides include starch, dextrins, pullulan, cellulose and derivatives, alginate, carrageenan, gums, pectins and chitosan. Polysaccharides render transparent and homogeneous edible films; these films are oxygen, aroma and oil barriers (due to their tightly-packed, ordered hydrogen-bonded network structure and low solubility), but are not effective moisture barriers due to their hydrophilic nature. However, when applied in the form of high-moisture gelatinous coatings, they can retard the moisture loss of food [15].

Proteins can be obtained from animal sources, such as casein and whey protein (the main milk protein fractions: $80 \%$ and $20 \%$, respectively), and from plant sources, such as zein, gluten and soy proteins [34].

Different proteins are able to form films and coatings; this ability depends on their molecular weight, conformations, electrical properties (charge vs. $\mathrm{pH}$ ), flexibilities and thermal stabilities [18]. Nevertheless, proteins have been studied less extensively than polysaccharides.

Generally, protein-based films have good oxygen, carbon dioxide and lipid barrier properties and mechanical properties; on the other hand, the poor water vapor resistance limits their application; this can be attributed to the inherent hydrophilicity of proteins.

As protein films are generally brittle and susceptible to cracking (due to the strong cohesive energy density of the polymers), an improvement of their properties could be attained by adding other components; for example, the addition of compatible plasticizers could improve their extensibility [35].

Edible lipid coatings include neutral lipids, fatty acids, waxes and resins. These compounds are effective in providing a moisture barrier and improving the surface appearance. Triglycerides or neutral lipids form a continuous stable layer on the food surface, thanks to their high polarity.

The growing interest addressed toward edible coatings leads to the formulation of new compositions consisting of blends of polysaccharides, proteins and lipids. The combination could be proteins and 
carbohydrates, proteins and lipids and carbohydrates and lipids [13], and it is based on the fact that each polymer has characteristic functions, that, when combined with each other, enhance the final functionality of the coating [15], improving the mechanical properties and, with emulsifiers, stabilizing composite coatings and improving coating adhesion.

Edible coatings can incorporate several compounds, such as: plasticizers (glycerol, acetylated monoglyceride, polyethylene glycol and sucrose), antimicrobials (bacteriocins (nisin)), enzymes (lysozyme, peroxidase and lactoperoxidase), essential oils (cinnamon, oregano, lemongrass, clove, rosemary, tea tree, thyme and bergamot), nitrites and sulfites [36], as well as synthetic antioxidants (butylated hydroxyanisole, butylated hydroxytoluene, propyl gallate, octyl gallate, dodecyl gallate, ethoxyquin, ascorbyl palmitate and tertiary butyl hydroquinone) and natural antioxidants (tocopherols, tocotrienols, ascorbic acid, citric acid, carotenoids). In these cases, edible films and coatings act as carriers of active compounds that, applied to the surface of fruits and vegetables, lead to the extension of shelf-life, the reduction of the risk of foodborne pathogenic microorganisms' growth on cut surfaces [37] and the improvement of the quality, stability and safety of coated foods [15].

\subsection{Edible Coating: A Focus on Chitosan}

Physical and chemical damage accrued during minimal processing of fruits and vegetables causes disruption of the plant tissues, and the exudates become ideal substrates for the growth of several microorganisms (pathogens, molds and bacteria). Natural biodegradable compounds with antimicrobial activity are recognized as safe (generally recognized as safe (GRAS)) and environmentally friendly, and chitosan is one such compound. Chitosan is able to create a semi-permeable film on the fruit surface, which results in limiting respiration and/or transpiration and in reducing weight loss [38,39]. Furthermore, its compatibility with other substances and its capability to induce host resistance to pathogens [40] have prompted its application as a coating on fruits and vegetables [41].

Chitosan has been widely used in controlling weight-loss in fresh strawberries (Fragaria x ananassa) and raspberries (Rubus idaeus), mango (Mangifera indica), litchi, blueberries and other fruit and vegetables [42]. Meng et al. [43] and Romanazzi et al. [44] reported that postharvest application of chitosan coating has a good control effect on decay of grapes. Chitosan owes its antimicrobial activity to its polycationic nature, which allows the interaction and formation of polyelectrolyte complexes with acid polymers produced at the surface of microbial cells, increasing their permeability and causing cell death [45].

Several factors affect the antimicrobial activity: type of chitosan, degree of acetylation, molecular weight, concentration, target microorganism, $\mathrm{pH}$ of the medium and presence of other additives or food components [46].

Benhabiles et al. [47] demonstrated that by reducing the number of steps for the synthesis and chemical reagents, chitosan coating was effective at improving the quality of strawberries by delaying changes in weight loss and the appearance of molds. These authors used three different chitosan coatings (chitosan $\mathrm{C} 1$ obtained by the classical method, chitosan $\mathrm{C} 2$ without decoloration and chitosan $\mathrm{C} 3$ without the decoloration and deproteinization steps) on strawberries, and they observed the best quality for the strawberries coated with C3 (1\%), which was obtained through a lesser number of steps. 
In a recent work, chitosan (in acid and water solution) exhibited its antibacterial activity against Burkholderia seminalis, an apricot fruit rot pathogen [48]. Lou and his coworkers demonstrated that acid-solution chitosan at a concentration of $2 \mathrm{mg} / \mathrm{mL}$ inhibited $B$. seminalis, while water-solution chitosan showed limited inhibition activity.

Chitosan has been proven to be a natural compound with antifungal activity for a wide varieties of postharvest fruits [38,49]. As reported by Bautista-Banos et al. [38], the level of inhibition of fungi is highly correlated to chitosan concentration. It is known that the polycationic nature of this compound is the key to its antifungal properties and that the length of the polymer chain enhances its antifungal activity. An additional explanation includes the possible effect that chitosan might have on the synthesis of certain fungal enzymes. El Ghaouth et al. [50] studied the antifungal effect of chitosan against Botrytis cinerea and Rhizopus stolonifer. These authors hypothesized that the mechanisms by which chitosan coating reduced the decay of strawberries appear to be related to its fungistatic properties, rather than to its ability to induce defense enzymes. A further confirmation of chitosan's ability to control fungal growth was reported by Park et al. [51]. They obtained a reduction of 2.5 and $2 \log \mathrm{CFU} / \mathrm{g}$ in the counts of Cladosporium sp. and Rhizopus sp., respectively, on strawberries coated with a chitosan-based edible film, just after the coating application. A reduction in the counts of aerobic and coliform microorganisms during storage has been also reported. Chien et al. [52] investigated the effects of coating with low and high molecular weight chitosan on the decay of citrus and the maintenance of its quality. A concentration of $0.2 \%$ low molecular weight chitosan (LMWC) exhibited its antifungal activity in controlling the growth of Penicillium digitatum and Penicillium italicum. LMWC coating resulted also in being able to improve firmness, titratable acidity, ascorbic acidity and the water content for citrus stored at $15^{\circ} \mathrm{C}$ for 56 days.

González-Aguilar et al. [53] have also reported a reduction in mesophilic aerobic microorganism count when fresh-cut papayas were coated with an edible coating based on chitosan of low and medium molecular weight. These researchers also observed a complete inhibition of yeast and molds throughout the storage (14 days at $5{ }^{\circ} \mathrm{C}$ ). As reported by Ali et al. [54], chitosan preserved papaya fruit, delaying the ripening process by reducing the respiration rate. These results could be the reason for the delayed senescence and reduced tendency to decay [40]. Chitosan had also made improvements in the taste, peel and pulp color, texture and flavor of treated papaya fruit, but the sensory features of the papaya fruits coated with a $1.5 \%$ chitosan concentration demonstrated overall superiority after five weeks of storage.

Pilon et al. [55] made an alternative use of chitosan. They obtained chitosan nanoparticles and demonstrated that chitosan, used as a coating based on nanoparticles, reduced the microbial growth in fresh-cut apples. The samples treated with chitosan-tripolyphosphate (CS-TPP) nanoparticles (10 nm) showed higher antimicrobial activity against mesophilic and psychrotrophic bacteria, as well as molds and yeasts than conventional chitosan coating and control [55].

Numerous papers have demonstrated that chitosan-based coatings inhibit microbial growth on fresh produce, increasing shelf-life.

In a recent paper, Benhabiles et al. [56] reported that chitosan coatings and a chitosan derivative (N,O-carboxymethyl chitosan (NOCC)) coating improved the quality of tomato fruits (through delaying ripening, reducing weight loss and retaining fruit firmness) and extended the shelf-life. No microbial growth was observed during storage. 
Assis and Pessoa [57] and Han et al. [58] proposed chitosan for extending the shelf-life of sliced apples and fresh strawberries, respectively. Chien et al. [52] reported the effectiveness of chitosan coating (at a concentration of $0.5 \%, 1 \%$ and $2 \%(\mathrm{w} / \mathrm{v})$ ) for prolonging the quality and extending the shelf-life of sliced mango fruit through a delay in the growth of mesophilic aerobic bacteria.

Durango et al. [59] and Devlieghere et al. [60] used a chitosan-based coating to cover carrots and lettuce, respectively, observing a reduction in the respiration rate and ethylene production, as well as a decrease in firmness loss. In particular, Durango et al. [59] controlled the growth of mesophilic aerobes, yeasts, molds and psychrotrophs of minimally-processed carrots during the first five days of storage at $15^{\circ} \mathrm{C}$ using an edible yam starch coating containing chitosan. Campaniello et al. [28] observed that chitosan coating in combination with low temperature and suitable packaging was able to control browning and decay in strawberry fruits. Chitosan affected the microbial growth (psychrotrophic, lactic acid bacteria and yeasts) and did not affect the visual appearance. $\mathrm{pH}$ and thickness values remained unchanged by chitosan coating, whereas color was positively influenced.

Pushkala et al. [61] investigated chitosan-based powder coating on radish shreds, demonstrating the favorable effects of two different forms of chitosan (purified chitosan $(\mathrm{CH})$ and chitosan lactate $(\mathrm{CL})$ ) on shelf-life extension of radish shreds by a minimum of $3 \mathrm{~d}$ over the control. Both CH- and CL-coated samples enhanced the microbial quality and sensory acceptability of the radish shreds, exhibiting a lower degree of weight loss, respiration rate, titrable acidity, \% of soluble solids, a higher content of phytochemicals, moisture and $\mathrm{pH}$, compared to control samples. The treated samples also exhibited lower exudate volume, lesser browning and lower microbial load compared to the control.

Sometimes, a chitosan-only coating demonstrated certain defects (including limited inhibition to some microorganisms that led fruit to decay and a poor coating structure); thus, chitosan was combined with other substances to improve its performance [62]. Chitosan coatings combined with organic acids are easy to handle, biodegradable and cause no harm to the coated fruit and/or vegetable [62]. For example, Yu et al. [63] combined 1\% phytic acid (known as inositol hexakisphosphate (IP6), inositol polyphosphate) with $1 \%$ chitosan to preserve fresh cut lotus root. This composite coating decreased the weight loss rate and malondialdehyde (MDA) content of fresh-cut lotus root, postponed browning, restrained the activities of peroxidase (POD), polyphenol oxidase (PPO) and phenylalanine ammonialyase (PAL) and maintained the content of vitamin $\mathrm{C}$ and polyphenol at a relatively high level.

Chitosan combined with natamycin significantly decreased fresh melon decay and weight loss caused by Alternaria alternata and Fusarium semitectum, two strains of spoilage fungi [64].

Zhang et al. [65] reported that chitosan was able to inhibit the growth of Botrytis cinerea and Rhizopus sp. by increasing the activities of various defense enzymes, such as $\beta$-1,3-glucanase (in orange, strawberries and raspberries) and phenylalanine ammonia-lyase (PAL) (in strawberries andtable grapes).

As expected, the antimicrobial activity of chitosan is also dependent on the food matrix; generally, the antimicrobial activity of chitosan is higher at a low $\mathrm{pH}$ because more of its amino groups are protonated; thus, it is able to interact with the negatively-charged surfaces inhibiting bacterial growth. Since the antimicrobial activity of chitosan is dependent on the charges on chitosan and the electrostatic forces, each food component could influence these interactions, affecting its activity.

Regarding this issue, Devlieghere et al. [60] published an interesting work on the interaction of chitosan and food components. The authors evaluated the effect of different food components (starch, 
proteins, $\mathrm{NaCl}$ and fat) on the antimicrobial activity of chitosan, following the growth of Candida lambica, a spoiling yeast strain, in a laboratory medium.

The authors reported that the higher concentrations of starch $(30 \%(\mathrm{w} / \mathrm{v}))$ inhibited the antimicrobial activity of chitosan, hypothesizing that it was due to a protective effect of starch or to electrostatic interactions when the starch was charged by modification. Proteins influenced the antimicrobial activity of chitosan depending on the $\mathrm{pH}$ of the medium, as their charges depend on the combination of the iso-electric point (IEP) of the proteins and the $\mathrm{pH}$ of the medium. If the $\mathrm{pH}$ is lower than the IEP, proteins and chitosan are positively charged; thus chitosan can exert its antimicrobial activity, as the interactions between both will be restricted. If the $\mathrm{pH}$ is higher than the IEP of the protein, the antimicrobial activity of chitosan is inhibited: proteins are negatively charged and neutralize most of the positive charges on the chitosan; thus, it cannot interact with the negatively-charged microbial surfaces [60].

$\mathrm{NaCl}$ reduces the antimicrobial activity of chitosan, because it interferes with the electrostatic forces between chitosan: $\mathrm{Cl}^{-}$ions neutralize the positive charges on the chitosan, and on the other hand, the $\mathrm{Na}^{+}$ions compete with chitosan for the negative charges on the cell surface. Devlieghere et al. [60] observed an improved solubility of chitosan by adding $\mathrm{NaCl}$ at different concentrations to the medium. The authors explained that this behavior was probably due to a shielding effect of $\mathrm{NaCl}$ against the positive charges, which led to a coiled structure of chitosan and less interactions with components in the media. Finally, the influence of fat on the antimicrobial activity of chitosan was found negligible.

The addition of the essential oils to enhance chitosan antimicrobial action is common.

The active agents embedded into composite films may be released into or absorb substances from the packaged food or its surrounding environment. The interactions that can occur between the food product, the film or coating used as packaging and the surrounding environment are governed by different mass transfer processes: migration, adsorption, absorption and permeation [66]. For example, through these processes, the essential oils included in the coating could be transferred to the product and modify its organoleptic and nutritional characteristics by interacting with peptides, vitamins, etc. It is recognized that some important food components, such as vitamins, minerals and other nutrients, can also be sequestered with the consequent modification of food properties and functionality. In addition, when transferred from the coating to the food to pursue their protective action (antioxidants, antimicrobials, etc.), these compounds could also lose their effectiveness. It is, in fact, well recognized that generally, the efficacy of various antimicrobial compounds may be reduced by food components; for example, essential oils (EOs) and/or their components have a significant antimicrobial activity in vitro, but higher amounts are required $(1 \%-3 \%)$ to achieve the same effect in foods. The presence of fat, protein, carbohydrate, water, salt, antioxidants, preservatives, other additives and $\mathrm{pH}$ reaction strongly influence the effectiveness of the natural compounds in foods.

High levels of fat and/or protein in foodstuffs protect bacteria from the action of EOs in some way. Some authors suggested that the fat provides a protective layer around the bacteria, or the lipid fraction could absorb the antimicrobial agent, thus decreasing its concentration and effectiveness in the aqueous phase [67]. Patrignani et al. [68] reported that the low fat content of vegetables may contribute to the successful use of EOs. Due to their lipophilic nature, EOs could share fat, missing the microbial target.

The $\mathrm{pH}$ is an important factor affecting the activity of oils. At a low $\mathrm{pH}$, the hydrophobicity of some EOs increases due to their ability to dissolve more easily in the lipid phase of the bacterial membrane, thus enhancing the antimicrobial action. 
Carbohydrates in foods do not protect bacteria from this action, whilst high water and/or salt level seems to facilitate the action of EOs.

The antibacterial activity of chitosan-based films combined with lemon (LO), tea tree (TTO) or bergamot essential oils (BO) was tested against two Gram-positive bacteria (Staphylococcus aureus and L. monocytogenes) and one Gram-negative bacteria (Escherichia coli) [69]. CH-EO composite films exhibited a significant antimicrobial activity against the three pathogens tested. The nature and concentration of the EOs, the film matrices and the interactions between $\mathrm{CH}$ and EOs affected the antimicrobial activity of the films. When TTO was added, $\mathrm{CH}$ exhibited the highest antimicrobial activity.

Chitosan-cinnamon oil coating extended the shelf-life of sweet pepper: after storage at $8{ }^{\circ} \mathrm{C}$ for 35 days, samples treated with chitosan-oil coatings showed a lower percentage of infected peppers and good sensory acceptability [70]. Sessa et al. [71] studied a novel approach to preserve vegetable products through modified chitosan edible coatings containing nanoemulsified natural antimicrobial compounds (lemon, mandarin, oregano or clove essential oils). A modified chitosan edible coating combined with lemon essential oil resulted in a remarkable increase in antimicrobial activity, with respect to other essential oils. This combination prolonged the shelf-life of rucola leaves from 3 to 7 days, in comparison to the untreated samples.

Moreover, the modified chitosan containing the nanoemulsified antimicrobial caused a significantly longer shelf-life also in comparison to a coating made of modified chitosan or essential oil alone. Thanks to this novel treatment, it was possible to prolong the shelf life of rucola leaf vegetables to about 10-14 days, without alteration of the organoleptic properties of the product, preventing the loss of firmness and color changes and preserving palatability during storage.

More recently, Randazzo et al. [72] used chitosan-based and methylcellulose-based films added to several EOs derived from citrus fruits (orange, mandarin and lemon) to perform the antilisterial assay and concluded that chitosan films containing essential oil from lemon were the most effective at reducing L. monocytogenes counts.

A chitosan-methyl cellulose-based film was used as a coating on cantaloupe fruit. The application of a chitosan $(1.5 \% \mathrm{w} / \mathrm{v}) /$ methyl cellulose $(0.5 \% \mathrm{w} / \mathrm{v})$ film on fresh-cut cantaloupe reduced populations of E. coli inoculated on fresh-cut cantaloupe by more than $5 \log \mathrm{CFU} /$ piece in 8 days at $10^{\circ} \mathrm{C}$. Furthermore, a reduction of $3 \log \mathrm{CFU} /$ piece of Saccharomyces cerevisiae in 4 days of storage at $10{ }^{\circ} \mathrm{C}$ was reported [73].

Krasaekoopt and Mabumrung [74] observed that the incorporation of $1.5 \%$ and $2 \%$ chitosan in the methylcellulose coating, applied on fresh-cut cantaloupe, produced a better microbiological quality in the final product. This coating reduced the growth of mesophilic aerobes, psychrotrophs, lactic acid bacteria, yeast and molds and prevented the multiplication of E. coli and Salmonella strains.

\section{Alternative Modified Atmospheres (e.g., High $\mathrm{O}_{2}$-MAP) or the Use of Essential Oils in the Headspace}

The final operation in producing minimally-processed fruits and vegetables is packaging.

Packaging performs several functions: it protects fresh-cut fruits and vegetables against deteriorative effects, contains the products, communicates to the consumers as a marketing tool and provides consumers products with ease of use and convenience. Fresh fruits and vegetables continue to respire, 
consuming oxygen and producing carbon dioxide and water vapor; thus, the atmosphere surrounding the package changes into another composition before sealing in vapor-barrier materials [75].

Modified atmosphere packaging (MAP) is a technique used for prolonging the shelf-life of fresh or minimally-processed foods [76]. MAP reduces the unwanted metabolic reactions and helps to protect processed products against contamination by microorganisms, thus slowing down the process of ageing [77]. MAP can be vacuum packaging (VP) and controlled atmosphere packaging (CAP). VP removes most of the air, or air is removed by vacuum or flushing and replaced with another gas mixture, before the product is packaged; the headspace atmosphere and product could change during storage, without additional manipulation of the internal environment. Differently, CAP continuously controls the environment to maintain a stable gas atmosphere within the package, as well as the temperature and humidity are monitored; it is generally used to control the ripening and spoilage of fruits and vegetables [76]. The composition, microflora, $\mathrm{pH}$ and the organoleptic characteristics of fruits and vegetables are extremely variable; therefore, it is impossible to define a univocal mixture of gases. It is necessary to maintain an optimum balance of oxygen and carbon dioxide; thus, an appropriate MAP must be studied for each product. Many factors affect the MAP of fresh produce and are summarized in Figure 2.

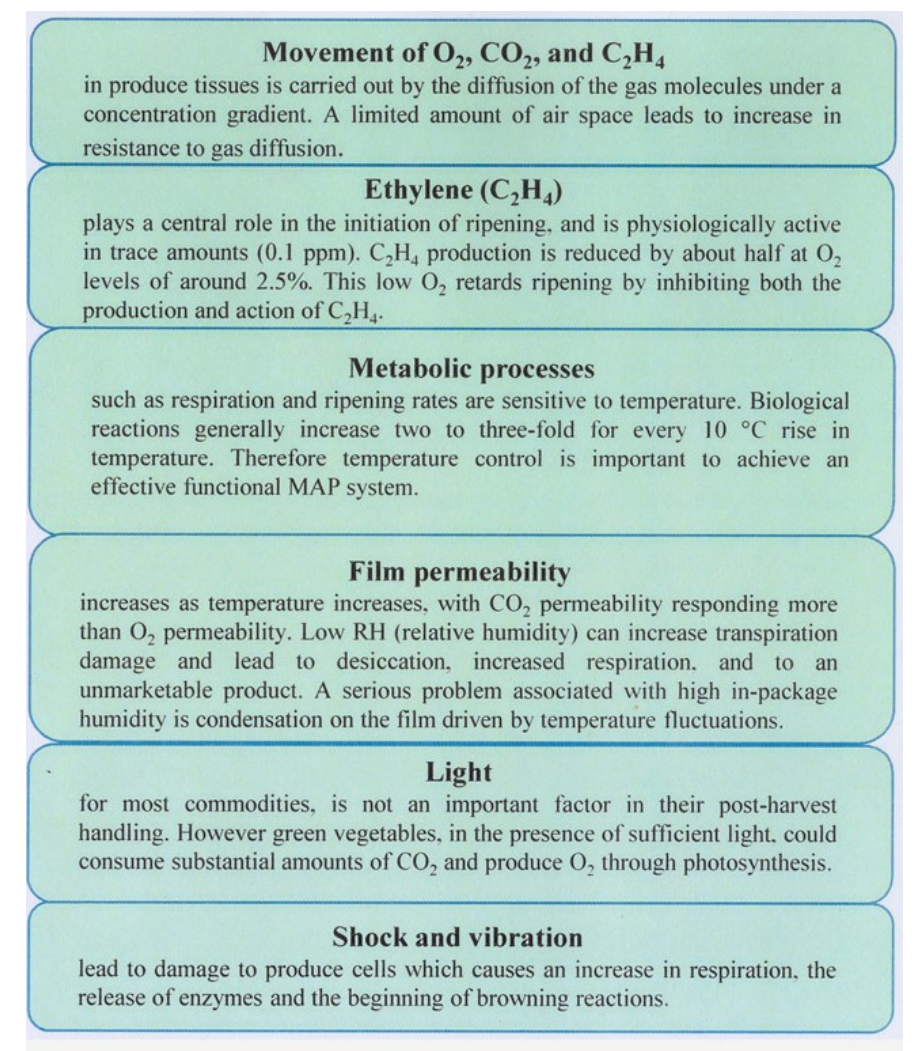

Figure 2. Factors affecting MAP of fresh products [76].

\subsection{Gases Used in MAP}

The main gases used in MAP are $\mathrm{CO}_{2}, \mathrm{O}_{2}$ and $\mathrm{N}_{2}$; carbon monoxide $(\mathrm{CO})$ and sulfur dioxide $\left(\mathrm{SO}_{2}\right)$ are also used. Noble gases, generally, are used for some products, such as coffee and snacks, but recently have been used also for minimally-processed apples and kiwi fruits [76]. The choice of gas depends on 
the food product being packed. Singly or in combination, these gases are commonly used to balance safe and shelf-life extension with optimal sensorial properties of the food. Table 2 reports the main gases used in MAP.

Low levels of oxygen and high levels of carbon dioxide reduce the produce respiration rate, delay senescence and, consequently, extend the shelf-life of fruits and vegetables. Once the package is closed, the composition of the gases inevitably changes due to produce respiration and the gas permeability of the film. If the oxygen levels are too low, fermentative processes are favored.

Table 2. Main gases used in MAP.

\begin{tabular}{|c|c|}
\hline Gases & Characteristics and Functions \\
\hline $\begin{array}{l}\text { Carbon Dioxide } \\
\qquad\left(\mathrm{CO}_{2}\right)\end{array}$ & $\begin{array}{l}\text { It is a colorless gas with a slight pungent odor at very high concentrations. It is an asphyxiant and } \\
\text { slightly corrosive in the presence of moisture. } \mathrm{CO}_{2} \text { is lipid soluble and also dissolves readily in water } \\
\text { to produce carbonic acid }\left(\mathrm{H}_{2} \mathrm{CO}_{3}\right) \text {, which causes an increase of the acidity of the solution, reducing } \\
\text { the } \mathrm{pH} \text {; this significantly affects the microbiology of packed foods. } \mathrm{CO}_{2} \text { has bacteriostatic and } \\
\text { fungistatic properties. This bacteriostatic effect depends on the concentration and partial pressure of } \\
\mathrm{CO}_{2} \text {, the volume of headspace gas, the type of microorganism, the age and load of the initial bacterial } \\
\text { population, the microbial growth phase, the growth medium used, the storage temperature, the } \\
\text { acidity, the water activity and the type of product being packaged [78-81]. As } \mathrm{MAP} \text { contains } \mathrm{CO}_{2} \text {, it } \\
\text { is not an advisable option for these products where spoilage yeasts are stimulated by high levels of } \\
\mathrm{CO}_{2} \text {. In addition, } \mathrm{CO}_{2} \text { is not effective towards Clostridium perfringens and Clostridium botulinum. } \\
\mathrm{Carbon} \text { dioxide is generally effective in fresh fruits and vegetables where the normal spoilage } \\
\text { organisms consist of aerobic, Gram-negative psychrotrophic bacteria. To guarantee the maximum } \\
\text { antimicrobial effect, low storage temperatures for } \mathrm{MAP} \text { are recommended, because } \mathrm{CO}_{2} \text { is most soluble } \\
\text { at low temperatures. The fat and moisture of the product affect the absorption of } \mathrm{CO}_{2} \text {. Fruits and } \\
\text { vegetables can suffer physiological damage due to high } \mathrm{CO}_{2} \text { levels. }\end{array}$ \\
\hline Oxygen $\left(\mathrm{O}_{2}\right)$ & $\begin{array}{l}\text { Oxygen is a colorless and odorless gas and is highly reactive. It has a low solubility in water and } \\
\text { promotes several deteriorative reactions in foods (fat oxidation, browning reactions and pigment } \\
\text { oxidation). Most of the common spoilage bacteria and fungi require oxygen for growth; therefore, } \\
\text { if the pack atmosphere contains a low concentration of oxygen, the shelf-life of foods is prolonged. } \\
\text { As an alternative to low oxygen concentrations, superatmospheric } \mathrm{O}_{2} \text { concentrations }(\geq 70 \mathrm{kPa} \text { ) have } \\
\text { been proposed. }\end{array}$ \\
\hline Nitrogen $\left(\mathrm{N}_{2}\right)$ & $\begin{array}{l}\text { Nitrogen is an inert, tasteless, colorless and odorless gas and is relatively un-reactive. It has a lower } \\
\text { density than air, is non-flammable and has a low solubility in water and other food constituents. } \\
\mathrm{N}_{2} \text { is used to balance } \mathrm{CO}_{2} \text { and } \mathrm{O}_{2} \text { gases during food packaging, thus preventing packaging collapse } \\
\text { that could occur when high concentrations of } \mathrm{CO}_{2} \text { are used. In addition, } \mathrm{N}_{2} \text { is able to delay oxidative } \\
\text { rancidity and inhibit the growth of aerobic microorganisms without affecting the growth of anaerobic } \\
\text { bacteria. Nitrogen can also indirectly influence the microorganisms in perishable foods by retarding } \\
\text { the growth of aerobic spoilage microorganisms. }\end{array}$ \\
\hline $\begin{array}{l}\text { Carbon Monoxide } \\
\qquad(\mathrm{CO})\end{array}$ & $\begin{array}{l}\text { CO is a colorless, tasteless and odorless gas; it has a low solubility in water, but it is relatively soluble } \\
\text { in some organic solvents. CO has been licensed for use in the USA to prevent browning in packed } \\
\text { lettuce. It is highly reactive and very inflammable, thus its commercial application has been limited. } \\
\text { Finally, CO has little inhibitory effect on microorganisms. }\end{array}$ \\
\hline Noble Gases & $\begin{array}{l}\text { These include helium }(\mathrm{He}) \text {, argon }(\mathrm{Ar}) \text {, xenon }(\mathrm{Xe}) \text { and neon }(\mathrm{Ne}) \text {. These gases are not very reactive } \\
\text { and are used in numerous food applications, e.g., potato-based snack products. }\end{array}$ \\
\hline
\end{tabular}


It is known that fresh-cut processing involves several forms of damage:

- Increases respiration rates;

- Causes major tissue disruption: enzymes and substrates, normally contained within the vacuole, are mixed with other cytoplasmic and nucleic substrates and enzymes;

- Increases wound-induced $\mathrm{C}_{2} \mathrm{H}_{4}$, water activity and surface area per unit volume, which lead to an accelerated water loss and favored microbial growth;

- Causes flavor loss;

- Causes cut surface discoloration or color loss;

- Causes decay;

- Causes increased rate of vitamin loss;

- Causes rapid softening;

- Causes shrinkage and a shorter storage life.

Thus, MAP facilitates the maintenance of fresh-cut products.

Actually, the safety of minimally-processed fruits and vegetables is mainly based on the correct chilling chain and hygienic practices, which seem to not be able to guarantee a sufficient degree of safety; in fact, the number of documented outbreaks of human infections associated with the consumption of these products has considerably increased. On these bases, traditional MAP is not enough to ensure the improvement of the quality and safety characteristics. In this context, many researchers have studied alternative tools, for improvement of MAP for minimally-processed fruits and vegetables; for example, the use of non-conventional atmospheres, including active packaging containing some natural antimicrobial compounds or MAP with high $\mathrm{O}_{2}$, has been proposed.

\subsection{MAP and Natural Antimicrobial Compounds}

Plants and plant products are generally considered natural alternatives to improve the shelf-life and the safety of foods, since they are characterized by a wide range of GRAS volatile compounds, which are used as food flavoring agents [76]. They are able to inhibit numerous microorganisms; thus they are used as components of biological means for prolonging the shelf-life of post-harvest or minimally-processed fruits and vegetables [76].

Literature data indicate that volatile compounds can represent a useful tool to increase the shelf-life of plant products. Corbo et al. [82] evaluated the effects of hexanal and trans-2-hexenal on the shelf-life of fresh sliced apples. The authors added trans-2-hexenal to the gas mixture containing $70 \% \mathrm{~N}_{2}$ and $30 \% \mathrm{CO}_{2}$ and found a significant extension of the shelf-life also when Pichia subpelliculosa (a spoilage yeast) was inoculated and abuse storage temperatures were used, although it had a weak negative effect on color retention.

Lanciotti et al. [83], postulated that future trends in the use of natural compounds, such as hexanal, 2-(E)-hexenal and hexyl acetate, would be focused on the use of specific active packaging able to release the active molecules in the head space slowly over time.

The authors reported that $150 \mathrm{ppm}$ of hexanal, $20 \mathrm{ppm}$ of 2-(E)-hexenal and $150 \mathrm{ppm}$ of hexyl acetate displayed a bactericidal effect on L. monocytogenes and caused a significant extension of the lag phase of E. coli and Salmonella Enteritidis inoculated at levels of $10^{4}-10^{5} \mathrm{CFU} / \mathrm{g}$ in fresh sliced apples packaged in ordinary or modified atmosphere. 
Campaniello et al. [84] investigated the possibility of combining hexanal and MAP $\left(65 \% \mathrm{~N}_{2}\right.$, $30 \% \mathrm{CO}_{2}$ and $5 \% \mathrm{O}_{2}$ ) on minimally-processed cactus pear fruits. The hexanal showed an antimicrobial effect against Enterobacteriaceae, normally contaminating minimally-processed fruits, both in the control and the modified atmosphere. The inclusion of the antimicrobial compound in the atmosphere determined an improvement of the original color retention; as well as a mesophilic selection favoring Pantoea spp., which have antagonistic activity against molds responsible for the decay of fruits during post-harvest phase.

Siroli et al. [85] proposed the use of several antimicrobial compounds (citron EO, hexanal, 2-(E)-hexenal, citral and carvacrol) alone or in combination in order to increase the shelf-life and quality parameters (texture and color) of sliced apples packaged in active modified atmosphere $\left(7 \% \mathrm{O}_{2}\right.$ and $0 \%$ $\mathrm{CO}_{2}$ ), into medium permeability bags and stored at $6{ }^{\circ} \mathrm{C}$. In all of the samples, the spoilage yeast threshold was not attained within the 35 days of storage. When treated with citral/2-(E)-hexenal and hexanal/2-(E)-hexenal, the sample showed a good color retention. This latter combination also improves on the retention of firmness, which was the best throughout 35 days of storage.

Furthermore, plant essential oils, constituted mainly by terpenoids, are used for their antimicrobial activity against many microorganisms. Most of the essential oils are GRAS; nevertheless, their use is often limited because of a high impact on the organoleptic characteristics of food products.

The activity of oils from Labiatae and citrus fruits, as well as the action of single constituents have been studied in order to better understand the cell targets of the molecules. Due to their antimicrobial effect, citrus essential oils could represent good candidates to improve the shelf-life and the safety of minimally-processed fruits. Essential oils, such as citrus, mandarin, cider, lemon and lime, were able to increase the shelf-life and safety of minimally-processed fruit salads without any impact on the sensory characteristics, even when the product was inoculated with spoilage or pathogenic bacterial species [76].

Citrus essential oils (EOs) exhibited their antimicrobial effect against a range of food poisoning-causing bacteria. A blend of citrus EO vapor against vancomycin-resistant (VRE) and vancomycin-susceptible (VSE) Enterococcus faecium and Enterococcus faecalis on lettuce and cucumber was assessed. Food samples were subjected to the vapor for $45 \mathrm{~s}$ in a $600-\mathrm{L}$ vapor chamber at $25^{\circ} \mathrm{C}$. Results showed that microbial cell load was reduced and that no significant changes in taste were observed [86].

Tian et al. [87] tested the antifungal activity of essential oil extracted from the fruits of Cicuta virosa L. var. latisecta Celak (CVEO) against Aspergillus niger, Aspergillus flavus, Aspergillus oryzae and Al. alternata strains inoculated on cherry tomatoes. The samples were pre-treated with ethanol and wounded with a sterilized cork borer; then, each fruit was separately inoculated with $10 \mu \mathrm{L}$ of a spore suspension containing $1 \times 10^{6}$ spores $/ \mathrm{mL}$ of each fungal strain. CVEO (dissolved separately in $0.5 \mathrm{~mL}$ of 5\% of Tween-20) was pipetted aseptically onto filter paper discs respectively placed into individual weighing bottles (without lids) to produce the concentrations of 200,100 and $50 \mu \mathrm{L} / \mathrm{mL}$. The essential oil was vaporized inside the containers spontaneously at $18{ }^{\circ} \mathrm{C}$. The authors reported that at $200 \mu \mathrm{L} / \mathrm{mL}$, CVEO showed the lowest percentages of decayed cherry tomatoes for all fungi compared to the control, as well as the highest inhibition of fungal infection.

In a recent paper, Vitoratos et al. [88] studied the antifungal activity of several essential oils obtained from oregano (Origanum vulgare L. ssp. hirtum), thyme (Thymus vulgaris L.) and lemon (Citrus limon L.) plants against Bo. cinerea inoculated in tomatoes, strawberries and cucumbers. All of the fruits were pre-treated and packaged. Different concentrations of essential oils were placed in small glass containers 
placed in the bottom of the package. Oregano and lemon oils were very effective at controlling disease of infected fruit by Bo. cinerea in tomatoes, strawberries and cucumbers. In particular, in tomatoes, Bo. cinerea was inhibited by oregano essential oils at $0.30 \mu \mathrm{L} / \mathrm{mL}$; moreover, lemon essential oils also induced a significant reduction of grey mold. An amount of $0.05 \mu \mathrm{L} / \mathrm{mL}$ of lemon essential oils leads to a complete inhibition of Bo. cinerea in strawberries, whilst in cucumber, it leads to a reduction (39\%) of the infected fruits.

\subsection{Potential Applications of High $\mathrm{O}_{2}$}

It is known that low $\mathrm{O}_{2}$ modified atmosphere packaging is universally accepted to prolong the shelf-life of minimally-processed fruits and vegetables; however, the growth of some anaerobic pathogen strains might be allowed or even stimulated. In addition, when $\mathrm{O}_{2}$ levels are too low, this induces anaerobic respiration, leading to fermentation processes and to the production of undesirable metabolites [89].

The application of high $\mathrm{O}_{2}$ concentrations $\left(>70 \% \mathrm{O}_{2}\right)$ could overcome the disadvantages of low $\mathrm{O}_{2}$ modified atmosphere packaging for some ready-to-eat fruits and vegetables. High $\mathrm{O}_{2}$ was found to be particularly effective at inhibiting enzymatic discoloration, preventing anaerobic fermentation reactions and inhibiting microbial growth [90]. It is hypothesized that high $\mathrm{O}_{2}$ levels may cause substrate inhibition of the enzyme polyphenol oxidase (PPO), which is the enzyme responsible for initiating discoloration on the cut surfaces of processed products [91].

High $\mathrm{O}_{2}$-modified atmosphere packaging has been used in some vegetables and fruits, such as minimally-processed carrots, strawberry, minimally-processed baby spinach, fresh-cut mango, apple slices, and so on [89].

Amanatidou et al. [92] screened numerous microorganisms (Pseudomonas fluorescens, Enterobacter agglomerans, Aureobacterium strains 27, Candida guilliermondii, Candida sake, Salmonella Typhimurium, Salmonella Enteritidis, E. coli, L. monocytogenes, Leuconostoc mesenteroides var. mesenteroides, Lactobacillus plantarum and Lactococcus lactis) associated with the spoilage and safety of minimally-processed vegetables. High oxygen levels $(80 \%-90 \%)$ caused a reduction in the growth rate of microbial targets at $8{ }^{\circ} \mathrm{C}$, whilst the lag phase was prolonged (it was more evident at $90 \% \mathrm{O}_{2}$ concentrations). Amanatidou et al. [92] and Kader and Ben Yehoshua [93] hypothesized that high $\mathrm{O}_{2}$ concentrations lead to intracellular generation of reactive oxygen radical species ( $\mathrm{ROS}, \mathrm{O}_{2}^{-}, \mathrm{H}_{2} \mathrm{O}_{2}, \mathrm{OH}^{-}$), causing damage to the vital cellular macromolecules, thus reducing cell viability when oxidative stresses overwhelm cellular protection systems.

Jacxsens et al. [90] studied the effect of high oxygen-modified atmosphere packaging (i.e., $\left.>70 \% \mathrm{O}_{2}\right)$ on microbial growth and the sensorial qualities of mushroom slices, grated celeriac and shredded chicory endive and observed that high $\mathrm{O}_{2}$ atmospheres were effective at inhibiting enzymatic browning of the tested vegetables. In addition, an improvement of the microbial quality (as a reduction in yeast growth) was obtained.

In an interesting paper, Allende et al. [94] studied the effect of superatmospheric oxygen packaging on sensorial quality, spoilage and L. monocytogenes and Aeromonas caviae growth in fresh processed mixed salads. An initial $\mathrm{O}_{2}$ concentration of $95 \mathrm{kPa}$ was combined with two plastic films (low and high 
barrier impermeability for $\mathrm{O}_{2}$ ). Packaged salads were stored up to eight days at $4{ }^{\circ} \mathrm{C}$ and at temperatures simulating the chilled distribution chain.

The authors reported that superatmospheric $\mathrm{O}_{2}$ does not affect all microorganisms in the same way: high oxygen levels affected lactic acid bacteria and Enterobacteriaceae, which were inhibited in both plastic films (with low and high permeability). On the contrary, the growth of yeast and A. caviae seemed to be stimulated, whereas the growth of psychrotrophic bacteria and L. monocytogenes was not affected. The general appearance was maintained for longer, and the shelf-life of the mixed salads was prolonged by using $\mathrm{O}_{2}$ concentrations higher than $60 \mathrm{kPa}$ throughout the storage period.

Chunyang et al. [89] studied the effect of high oxygen-modified atmosphere packaging on fresh-cut onion quality at room temperature. Onion slices were packaged in a high-barrier film package of $70 \mu \mathrm{m}$ in thickness and stored in five different modified atmospheres $\left(100 \% \mathrm{O}_{2} ; 95 \% \mathrm{O}_{2} / 5 \% \mathrm{CO}_{2}\right.$; $80 \% \mathrm{O}_{2} / 20 \% \mathrm{CO}_{2}, 75 \% \mathrm{O}_{2} / 25 \% \mathrm{CO}_{2}$; and air). Results showed that the fresh-cut onions packaged in air had a short shelf-life, because the respiration rate was quickened due to mechanical damage, and microorganisms were not inhibited. High $\mathrm{O}_{2}$ reduced the weight loss, the respiration rate, the total reducing sugar loss and the total titrable acidity increase of the fresh-cut onions. The best modified atmosphere seemed to be $80 \% \mathrm{O}_{2} / 20 \% \mathrm{CO}_{2}$, where total bacteria counts increased slowly. High oxygen affected also the sensory characteristics: sensory quality was acceptable up to five days, while air-packaged fresh-cut onions were not acceptable after two days of storage at room temperature.

Day [91] also confirmed that the most effective high $\mathrm{O}_{2}$ gas mixtures were found to be $80 \%-85 \% \mathrm{O}_{2} / 15 \%-20 \% \mathrm{CO}_{2}$. This had the most noticeable sensory quality and antimicrobial benefits on a range of freshly-prepared produce items.

In fact, recommended optimal headspace gas levels immediately after freshly-prepared produce package sealing are: $80 \%-95 \% \mathrm{O}_{2}$ and $5 \%-20 \% \mathrm{~N}_{2}$. After package sealing, headspace $\mathrm{O}_{2}$ levels will decline, whereas $\mathrm{CO}_{2}$ levels will increase during storage, due to the intrinsic respiratory nature of fresh product.

The levels of $\mathrm{O}_{2}$ and $\mathrm{CO}_{2}$ within packages are influenced by numerous variables:

- Intrinsic produce respiration rate (which itself is affected by temperature, atmospheric composition, produce type, variety, cultivar, maturity and the severity of preparation);

- Packaging film permeability;

- Package volume;

- Surface area and fill weight;

- Produce volume/gas volume ratio;

- Degree of illumination.

It would be preferable to maintain headspace levels of $\mathrm{O}_{2}>40 \%$ and $\mathrm{CO}_{2}$ between $10 \%$ and $25 \%$ to maximize the benefits of high $\mathrm{O}_{2}$ MAP. This can be achieved by:

- Lowering the temperature of storage;

- Selecting produce having a lower intrinsic respiration rate;

- Minimizing cut surface tissue damage;

- Reducing the ratio of produce volume/gas;

- Using a packaging film able to maintain high levels of $\mathrm{O}_{2}$ whilst allowing excess $\mathrm{CO}_{2}$ to go out 
- By incorporating an innovative active packaging sachet that can absorb excess $\mathrm{CO}_{2}$ and emit an equal volume of $\mathrm{O}_{2}$.

A further measure to maintain a gas mixture $\mathrm{O}_{2}>40 \% / \mathrm{CO}_{2} 10 \%-25 \%$ could be obtained by introducing the highest level of $\mathrm{O}_{2}$ (balanced with $\mathrm{N}_{2}$ ) possible just prior to prepared produce package sealing. Generally, it is not necessary to have any levels of $\mathrm{CO}_{2}$ in the initial gas mixture, since it will increase rapidly during chilled storage.

Numerous products (iceberg lettuce, sliced mushrooms, broccoli florets, lettuce, baby-leaf spinach, Lollo Rossa lettuce, flat-leaf parsley, cubed swede, coriander, raspberries, strawberries, grapes and oranges) processed with high $\mathrm{O}_{2}$ MAP reported beneficial effects on sensory quality if compared to industry-standard air packing and low $\mathrm{O}_{2}$ MAP [91].

Finally, the recommended packaging material for high $\mathrm{O}_{2}$-modified atmosphere is $30-\mu \mathrm{m}$ orientated polypropylene (OPP), which has sufficient $\mathrm{O}_{2}$ barrier properties (to maintain high in-pack $\mathrm{O}_{2}$ levels $>40 \%$ ), and it is sufficiently permeable to ensure that $\mathrm{CO}_{2}$ did not rise above $25 \%$ after $7-10$ days of storage at $5-8{ }^{\circ} \mathrm{C}$.

Other packaging materials suitable for high $\mathrm{O}_{2} \mathrm{MAP}$ of fresh prepared produce are:

- Laminations or extrusions of OPP with low density polyethylene (LDPE);

- Ethylene-vinyl acetate (EVA);

- Polyvinyl chloride (PVC).

or other medium to very high $\mathrm{O}_{2}$ permeability films.

\section{Conditioning Solutions with Antimicrobials or Natural Compounds for Fruit Salad}

Coatings, dipping, spraying, etc., are the main applications of antimicrobial compounds, as natural alternatives to chemical additives, whilst little is known about the use of antimicrobials as filling liquids.

An initial work by Senesi et al. [95] on the use of rectified apple juice as a filling liquid to increase the quality and shelf-life of fresh-cut apples was followed, more recently, by D'Amato et al. [96]. The authors evaluated the possibility of using a chitosan, honey and pineapple juice solution as filling liquids to prolong the microbiological shelf-life of a fruit-based salad.

"Granny Smith" apples, "Gialla" first crop cactus pear fruits and "Regina" table grapes were washed; then, apples and cactus pears were peeled and sliced, while grapes were cut without seeds. Mixed fruits were placed in conical frustum-shaped cups, filled with four different solutions (sterile distilled water as the control; $30 \%$ of acacia honey and $70 \%$ of distilled water; $50 \%$ of pineapple juice and $50 \%$ of distilled water; $50 \%$ of low molecular weight chitosan solution and $50 \%$ of sterile distilled) and stored at 4,8 and $12{ }^{\circ} \mathrm{C}$.

The authors observed that the use of the natural antimicrobial compounds, as a filling liquid, affected the microbiological shelf-life of salad.

At $4{ }^{\circ} \mathrm{C}$, mesophilic and psychrotrophic bacteria did not reach the established limit $\left(1 \times 10^{6} \mathrm{CFU} / \mathrm{g}\right)$ during the whole storage period (14 days), in samples with honey and chitosan solutions, whereas it ranged from about 6.34-7.81 days and from 9.38 to 11.49 for the control and samples with pineapple juice, respectively. 
At $8{ }^{\circ} \mathrm{C}$, all of the samples were stored for 10 days. For the samples treated with honey and chitosan solutions, psychrotrophic bacteria did not reach the established limit during the storage, while in control and pineapple juice, it was of 5-6 days. Concerning mesophilic bacteria, microbiological shelf-life was strongly reduced in the control samples and in pineapple juice (about 3.7-4.3 days), whilst in chitosan and honey, it was over six days. In addition, in the samples with chitosan solution, the microbiological shelf-life, calculated by using the growth of yeasts, was over seven days and, by using lactic acid bacteria, did not reach the established limit.

At $12{ }^{\circ} \mathrm{C}$, the samples were stored for six days. The microbiological shelf-life of fruit salad without antimicrobial compounds and with pineapple juice was always very low (1.5 and 4 days, respectively).

In the samples honey added, mesophilic and psychrotrophic bacteria did not reach the limit of $1 \times 10^{6} \mathrm{CFU} / \mathrm{g}$. For lactic acid bacteria and yeasts, microbiological shelf-life reached 3.82 and 1.81 days, respectively.

Chitosan exhibited its high antimicrobial activity towards psychrotrophic bacteria, which did not reach the established limit, while no advantage resulted for mesophilic bacteria and lactic acid bacteria and yeasts.

The authors concluded that:

- Honey inhibited mesophilic and psychrotrophic bacterial growth; the antimicrobial activity of this natural antimicrobial compound was less effective on lactic acid bacteria and yeasts at all storage temperatures;

- Chitosan exerted a high antimicrobial activity for all microbial groups considered, particularly at a low temperature of storage;

- Pineapple juice was not effective towards all microbial groups, probably due to the high amount of nutrients.

Further investigations are needed to improve the antimicrobial efficacy of honey and chitosan for potential commercial applications. The literature is poor in articles addressing this topic; thus, it would be advisable to explore the use of antimicrobial compounds as filling liquids.

\section{Biopreservation and the Use of Probiotic Coatings}

In recent years, biological preservation has emerged as a promising strategy to extend the shelf-life and to improve the microbiological safety of foods [97], since it fits well with the diffuse desire to preserve foods by natural means. Several bacteria and yeasts have been already identified as bioprotective agents [98], and different studies have been carried out on their application to fresh-cut fruits and vegetables [99]. Table 3 summarizes the most recent studies performed on this topic.

In general, lactic acid bacteria (LAB) have shown the greatest potential as biocontrol agents of several minimally-processed foods, because they are widely used in fermented foods and have a long history of safe use [100]. However, several other bacteria and yeasts, often selected among the naturally-occurring microflora, including strains of Pseudomonas syringae, Pseudomonas graminis, Gluconobacter asaii, Candida spp., Dicosphaerina fagi, Metschnikowia pulcherrima and C. sake, have been proposed as biocontrol agents in fresh-cut fruits and vegetables [101-104]. 
Table 3. Overview of the most recent studies performed on the use of biocontrol microorganisms to biopreserve minimally-processed products.

\begin{tabular}{ccc}
\hline Minimally-Processed Product & Proposed Microorganisms & Reference \\
\hline Biopreservation & & {$[103]$} \\
\hline Apples & Leuconostoc mesenteroides, Leuconostoc citreum & {$[102,105]$} \\
Apples & Pseudomonas graminis & {$[101]$} \\
Apples & Candida sake & {$[106]$} \\
Apples & Candida sp., Gluconobacter asaii, Dicosphaerina fagi, & {$[107]$} \\
Apples & Metschnikowia pulcherrima & {$[99]$} \\
Apples & Enterobacteriaceae & {$[108]$} \\
Apples & Lactobacillus plantarum & {$[103]$} \\
Iceberg lettuce & Lactococcus lactis & {$[104]$} \\
Iceberg lettuce & Leuconostoc spp. & {$[99]$} \\
Lamb's lettuce & Leuconostoc mesenteroides, Leuconostoc citreum & {$[109]$} \\
Melon & Lactobacillus plantarum, Lactobacillus casei & {$[110]$} \\
Melon & Pseudomonas graminis & {$[107]$} \\
Peaches & Pseudomonas graminis & {$[111]$} \\
Scarola salad & Enterobacteriaceae & \\
\hline Probiotic Biopreservation & Lactobacillus casei & {$[112]$} \\
Apple & & {$[113]$} \\
Apple & Lactobacillus rhamnosus GG & {$[114]$} \\
Papaya & Lactobacillus rhamnosus GG & {$[114]$} \\
\hline
\end{tabular}

The success of LAB in preventing the growth and activity of undesirable microorganisms is due to a large diversity of mechanisms of action related to the production of antimicrobial compounds, organic acids, hydrogen peroxide, bacteriocins and diacetyl $[103,104,115]$. The combination of low $\mathrm{pH}$ values and antibacterial activities of organic molecules produced by LAB remains the main mechanism for biopreservation [97]. Several bacteriocin-producing LAB have been shown to be effective against spoilage and pathogenic microorganisms in minimally-processed fruits and vegetables [116,117]. However, the direct application of bacteriocins to fresh-cut products did not provide completely satisfactory results probably due to the adsorption or inactivation of the added compound into the food product [116]; on the other hand, the direct use of living bacteriocinogenic bioprotective strains could lead to a more effective protection of the food product by circumventing the mentioned problems because of the localized and constant delivery of the antibacterial compound, which will add to other advantages, like space colonization by the strain [116,117]. The inhibitory properties against contaminating foodborne pathogens and spoilage microorganisms could also consist of a mere competition for nutrients (vitamins, minerals, trace elements and peptides), and therefore, via competition or antibiosis, LAB are able to function as a hurdle to pathogen growth and survival [118].

In the last decade, different LAB species were proposed as biocontrol agents in minimally-processed fruits and vegetables (see Table 3). In 2004, Scolari and Vescovo [111] performed several challenge tests on salad leaves by simultaneously inoculating Lactobacillus casei and various pathogens (S. aureus, Aeromonas hydrophila, E. coli and L. monocytogenes). A significant inhibitory effect by the LAB 
towards all of the pathogenic strains was observed and confirmed by the same authors during a subsequent study about the influence of Lb. plantarum on the growth of $S$. aureus [119]. Trias et al. [103] found five strains of LAB (some Leuconostoc spp. strains) that were able to inhibit L. monocytogenes and Salmonella Typhimurium in cut iceberg lettuce leaf, but were not effective in reducing the amount of E. coli. More recently, Siroli et al. [108] showed the good performance of a nisin-producing strain of Lc. lactis, which was able to inhibit L. monocytogenes, E. coli and the total mesophilic species when added at a level of $7 \log C F U / m L$ in the washing solution of minimally-processed lamb's lettuce and combined or not with thyme essential oil. In 2015, the same authors proposed two other LAB strains ( $L$ b. plantarum V7B3 and Lb. casei V4B4) to be used as biocontrol agents alone or in combination with thyme essential oil (EO) in lamb's lettuce [99]. In this work, the use of the Lb. plantarum V7B3 strain (6 log CFU/mL) during the washing phase of fresh-cut lettuce increased product shelf-life and safety; L. monocytogenes and E. coli viabilities were significantly reduced over the nine days of refrigerated storage. Promising results were also obtained for biopreservation of minimally-processed golden delicious apples packaged in a modified atmosphere alone or in combination with natural antimicrobials (2-(E)-hexenal/hexanal and 2-(E)-hexenal/citral) [99]: a strain of $\mathrm{Lb}$. plantarum (CIT3) was able to increase the safety of sliced apples, when inoculated at levels of 6-7 $\log \mathrm{CFU} / \mathrm{g}$ in the washing dipping solution, both alone or in combination with natural antimicrobials.

Other non-lactic acid bacteria and yeasts were also proposed as biocontrol agents (Table 3) For example, the growth of L. monocytogenes and Salmonella Enterica in fresh-cut apples has been prevented using fungal antagonists [106]. When inoculated at a low level, L. monocytogenes cell loads were greatly reduced (from 5.7 to $6.0 \mathrm{log}$ units after seven days) by strains of G. asaii, Candida spp., D. fagi and M. pulcherrima. At high pathogen inoculum levels, only G. asaii and Candida spp. reduced the cell load of L. monocytogenes population to non-detectable levels. Abadias et al. [101] found that the application of the fungal postharvest antagonist $C$. sake CPA-1 reduced the growth of a mixture of $E$. coli strains in fresh-cut apples at $25^{\circ} \mathrm{C}$, whereas Alegre et al. [107] isolated a new strain of Enterobacteriaceae that reduced the growth of Salmonella, L. monocytogenes and E. coli O157:H7 on fresh-cut apples and peaches. $P$. graminis was found be able to reduce or slow down the development of foodborne pathogens on minimally-processed fresh-cut apples and peaches [105]; in this case, the inhibitory effect of the antagonists on the foodborne pathogens was not instantaneous and became apparent after 6 days at $5{ }^{\circ} \mathrm{C}$. This strain was also proposed for fresh-cut melon, reducing Salmonella and L. monocytogenes growth during storage at 5, 10 and $20{ }^{\circ} \mathrm{C}$ [109]. The strain effectiveness depended on the pathogens' concentration and on storage temperature. At a low pathogen concentration and $20^{\circ} \mathrm{C}$, L. monocytogenes growth was reduced between 2.1 and $5.3 \mathrm{log}$ CFU/g after two days of storage and Salmonella growth between 2.0 and $7.3 \log \mathrm{CFU} / \mathrm{g}$.

Although research on the use of biocontrol agents in minimally-processed fruits and vegetables has increased in recent decades, the standardization of a biopreservative approach is still difficult to realize. Independent of the species and strains proposed, in fact, the various studies available in the literature clearly highlight that the efficacy of biocontrol agents is affected by different factors, such as the inoculation level, the presence of other bacteria, the physico-chemical and compositional features of the products and the storage conditions. Further investigations are required, especially considering that process conditions have to be taken into account, during the scaling up at the industrial level. 
An interesting modern challenge is to incorporate probiotic bacteria into coated processed fruits and vegetables in order to improve their shelf-life (biopreservation), while providing new non-dairy functional foods. As is well accepted, edible films/coatings may serve as carriers of food additives, such as anti-browning agents, antimicrobials, colorants, flavors, nutrients and spices [24]. Some authors $[114,120]$ proved that the coatings were also good carriers for antioxidant agents, such as cysteine, glutathione and ascorbic and citric acids; thus, the addition of LAB to obtain functional edible films and coatings could have successful implications. Several studies were already conducted on different fruits, as is shown in Table 3. This new trend has arisen from more considerations. As just mentioned, the inclusion into coatings of cultures with inhibitory properties could improve the shelf-life and safety of minimally-processed products, while reducing the need to use increasing levels of chemical additives [118]. In addition, the steps of minimally-processing vegetables, such as peeling and cutting, promote the release of cellular content rich in minerals, sugars, vitamins and other nutrients, creating ideal conditions for microbial growth: this characteristic allows the use of fruit and vegetable food products as probiotic carriers. According to Soccol et al. [121], in fact, minimally-processed fruits and vegetables are very good matrices providing ideal substrates for probiotics, since they contain minerals, vitamins, antioxidants and fibers. Moreover, due to their cellulose content, fruits, such as apples and pears, may also exert a protective effect on the probiotic microorganisms during passage through the intestinal tract [122], allowing these microorganisms to reach the colon and benefit the host. It has been reported that the optimum probiotic growth temperature is between 35 and $40{ }^{\circ} \mathrm{C}$, and the best $\mathrm{pH}$ is between 6.4 and 4.5 , ceasing when a $\mathrm{pH}$ of 4.0-3.6 is reached [123]. This situation could be solved by using some supports, such as agar, polyacrylamide, calcium pectate gel, chemically-modified chitosan beads and alginates, to provide a physical barrier against unfavorable conditions [124-126].

One of the first reports about this issue is the study of Tapia et al. [114]; fresh-cut apple and papaya cylinders were coated with $2 \%(\mathrm{w} / \mathrm{v})$ alginate or gellan film-forming solutions containing viable Bifidobacteria, namely Bifidobacterium lactis Bb-12. The bifidus-containing coatings were more permeable to water vapor than the corresponding films without probiotics, and gellan coatings were more resistant to water transfer than the alginate ones. The most important result was that the edible coatings were efficient in supporting Bb. lactis Bb-12 on fresh-cut apple and papaya. In 2010, Rößle et al. [112] applied a probiotic microorganism (Lactobacillus rhamnosus GG; LGG) to fresh-cut apple wedges (cultivar Braeburn). All samples were able to maintain a probiotic load of about $\mathrm{ca} .10^{8}$ $\mathrm{CFU} / \mathrm{g}$ over 10 storage days, which is sufficient for a probiotic effect, and this is comparable to the counts of probiotic bacteria in commercially-available dairy products. It is also important to underline that the physico-chemical properties of the apple wedges containing LGG compared to the control (without probiotics) remained stable over the observation period. In a subsequent work [113], the effectiveness as a biocontrol agent of the same probiotic strain against Salmonella and L. monocytogenes on minimally-processed apples throughout storage, as well as its effect on apple quality and natural microflora was evaluated. The obtained results showed that Salmonella was not affected by co-inoculation with LGG, whereas the L. monocytogenes population was 1-log unit lower in the presence of probiotic population maintained over recommended levels for probiotic action $\left(10^{6} \mathrm{CFU} / \mathrm{g}\right)$ along 14 days.

Although still unexplored, this new challenge appears to be highly advantageous, since minimally-processed fruits and vegetables are a food category rich in nutrients, intended for consumption by all individuals 
and widely accepted among consumers [127]. Thus, edible coatings, including probiotic bacteria, when applied to minimally-processed products, open new possibilities to improve their shelf-life and safety while providing innovative functional foods.

\section{Concluding Remarks}

The use of non-conventional tools to preserve and prolong the quality of minimally-processed fruits and vegetables seems to be the future trend to obtain improved final products. In particular, the application of the antimicrobial compounds into coatings and/or filling liquids should be further investigated due to their environmental friendliness and versatility. A combined approach of these technologies, through additive and synergistic interactions, could be useful to obtain innovative and safe minimally-processed products.

\section{Author Contributions}

The authors contributed equally to this paper.

\section{Conflicts of Interest}

The authors declare no conflict of interest.

\section{References}

1. Allende, A.; Tomas-Barberan, F.A.; Gil, M.I. Minimal processing for healthy traditional foods. Trends Food Sci. Tech. 2006, 7, 179-186.

2. Lamikanra, O. Preface. In Fresh-Cut Fruits and Vegetables; Lamikanra, O., Ed.; CRC Press: Boca Raton, FL, USA, 2002.

3. Gonzales-Aguilar, G.A.; Ayala-Zavala, J.F.; de La Rosa, L.A.; Ivarez-Parrilla, E.A. Preserving quality of fresh-cut product using safe technology. J. Verbrauch. Lebensm. 2010, 5, 65-72.

4. Boesso Oriani, V.; Molina, G.; Chiumarelli, M.; Pastore, G.M.; Dupas Hubinger, M. Properties of cassava starch-based edible coating containing Essential Oils. J. Food Sci. 2014, 79, E189-E194.

5. McHugh, T.H.; Senesi, E. Apple wraps: A novel method to improve the quality and extend the shelf life of fresh-cut apples. J. Food Sci. 2000, 65, 480-485.

6. Nisperos-Carriedo, M.O.; Baldwin, E.A.; Shaw, P.E. Development of an edible coating for extending postharvest life of selected fruits and vegetables. Proc. Fla. State Hort. Soc. 1991, 104, $122-125$.

7. Lerdthanangkul, S.; Krochta, J.M. Edible coating effects on post harvest quality of green bell peppers. J. Food Sci. 1996, 61, 176-179.

8. Avena-Bustillos, R.J.; Krochta, J.M.; Saltveit, M.E. Water vapor resistance of red delicious apples and celery sticks coated with edible caseinate-acetylated monoglyceride films. J. Food Sci. 1997, 62, 351-354.

9. Guilbert, S.; Gontard, N.; Gorris, L.G.M. Prolongation of the shelf-life of perishable food products using biodegradable films and coatings. LWT_Food Sci. Technol. 1996, 29, 10-17. 
10. Smith, S.; Geeson, J.; Stow, J. Production of modified atmospheres in deciduous fruits by the use of films ad coatings. Hort. Sci. 1987, 22, 772-776.

11. Krochta, J.M.; Mulder-Johnston, C.D. Edible and biodegradable polymer films: Challenges and opportunities. Food Technol. 1997, 51, 61-74.

12. Souza, B.W.S.; Cerqueira, M.A.; Teixeira, J.A.; Vicente, A.A. The use of electric fields for edible coatings and films development and production: A review. Food Eng. Rev. 2010, 2, 244-255.

13. Campos, C.A.; Gerschenson, L.N.; Flores, S.K. Development of edible films and coatings with antimicrobial activity. Rev. Food Bioprocess. Technol. 2010, 4, 849-875.

14. Allen, L.; Nelson, A.I.; Steinberg, M.P.; McGill, J.N. Edible corn-carbohydrate food coatings. Development and physical testing of starch-algin coating. Food Technol. 1963, 17, 1437-1442.

15. Lin, D.; Zhao, Y. Innovations in the development and application of edible coatings for fresh and minimally processed fruits and vegetables. Compr. Rev. Food Sci. Food Saf. 2007, 6, 60-75.

16. Diab, T.; Biliaderis, C.G.; Gerasopoulos, D.; Sfakiotakis, E. Physicochemical properties and application of pullulan edible films and coatings in fruit preservation. J. Sci. Food Agric. 2001, 81, 988-1000.

17. Synowiec, A.; Gniewosz, M.; Kraśniewska, K.; Przybył, J.L.; Bączek, K.; Węglarz, Z. Antimicrobial and antioxidant properties of pullulan film containing sweet basil extract and an evaluation of coating effectiveness in the prolongation of the shelf life of apples stored in refrigeration conditions. Inn. Food Sci. Emer. Technol. 2014, 23, 171-181.

18. Vargas, M.; Pastor, C.; Chiralt, A.; McClements, D.J.; González-Martínez, C. Recent advances in edible coatings for fresh and minimally processed fruits. Crit. Rev. Food Sci. 2008, 48, 496-511.

19. Coma, V.; Deschamps, A.; Martial-Gros, A. Bioactive packaging materials from edible chitosan polymer-antimicrobial assessment on dairy related contaminants. J. Food Sci. 2003, 68, 2788-2792.

20. Li, P.; Barth, M.M. Impact of edible coatings on nutritional and physiological changes in lightly processed carrots. Postharvest Biol. Tec. 1998, 14, 51-60.

21. Amanatidou, A.; Slump, R.A.; Gorris, L.G.M.; Smid, E.J. High oxygen and high carbon dioxide modified atmospheres for shelf life extension of minimally processed carrots. J. Food Sci. 2000, 65, 61-66.

22. Hershko, V.; Nussinovitch, A. Relationships between hydrocolloid coating and mushroom structure. J. Agric. Food Chem. 1998, 46, 2988-2997.

23. Bryan, D.S. Prepared citrus fruit halves and method of making the same. U.S. Patent 3,707,383, 26 December 1972.

24. Lee, J.Y.; Park, H.J.; Lee, C.Y.; Choi, W.Y. Extending shelf-life of minimally processed apples with edible coatings and antibrowning agents. Lebens. Wissen. Technol. 2003, 36, 323-329.

25. Arnold, F.W. Infrared Roasting of Coated Nutmeats. U.S. Patent 3,383,220, 14 May 1968.

26. Maftoonazad, N.; Ramaswamy, H.S.; Moalemiyan, M.; Kushalappa, A.C. Effect of pectin-based edible emulsion coating on changes in quality of avocado exposed to Lasiodiplodia theobromae infection. Carbohyd. Polym. 2007, 68, 341-349.

27. Vargas, M.; Albors, A.; Chiralt, A.; Gonzalez-Martinez, C. Quality of cold-stored strawberries as affected by chitosan-oleic acid edible coatings. Postharvest Biol. Tec. 2006, 41, 164-171. 
28. Campaniello, D.; Bevilacqua, A.; Sinigaglia, M.; Corbo, M.R. Chitosan: Antimicrobial activity and potential applications for preserving minimally processed strawberries. Food Microbiol. 2008, 25, 992-1000.

29. Krochta, J.M.; Pavlath, A.E.; Goodman, N. Edible films from casein-lipid emulsions for lightly-processed fruits and vegetables. In Engineering and food, Preservation Processes and Related Techniques; Spiess, W.E.; Schubert, H., Eds.; Elsevier Science Publishers: New York, NY, USA, 1990; pp. 329-340.

30. Trezza, T.A.; Krochta, J.M. Application of edible protein coatings to nut and nut-containing food products. In Protein-Based Films and Coatings; Gennadios, A., Ed.; CRC Press: Boca Raton, FL., USA, 2002; pp. 527-549.

31. Chan, M.A.; Krochta, J.M. Grease and oxygen barrier properties of whey-protein isolate coated paperboard. Solutions 2001, 84, 57.

32. Lin, S.Y.; Krochta, J.M. Plasticizer effect on grease barrier properties of whey protein concentrate coatings on paperboard. J. Food Sci. 2003, 68, 229-233.

33. Guilbert, S. Technology and application of edible protective films. In Food Packaging and Preservation; Mathlouthi, M., Ed.; Elsevier Applied Science Publishers: London, UK, 1986; pp. 371-394.

34. Gennadios, A.; McHugh, T.H.; Weller, G.L.; Krochta, J.M. Edible coatings and films based on proteins. In Edible Coatings and Films to Improve Food Quality; Krochta, J.M., Baldwin, E.A., Nisperos-Carriedo, M.O., Eds.; Technomic Publishing Co., Inc.: Lancaster, PA, USA, 1994; pp. 201-277.

35. Lim, L.T.; Mine, Y.; Britt, I.J.; Tung, M.A. Formation and properties of egg white protein films and coatings. In Protein-Based Films and Coatings; Gennadios, A., Ed.; CRC Press: Boca Raton, FL, USA, 2002; pp. 233-252.

36. Franssen, L.R.; Krochta, J.M. Edible coatings containing natural antimicrobials for processed foods. In Natural Antimicrobials for Minimal Processing of Foods; Roller, S., Ed.; CRC Press: Boca Raton, FL, USA, 2003; pp. 250-262.

37. Martín-Belloso, O.; Rojas-Graü, M.A.; Soliva-Fortuny, R. Delivery of flavor and active ingredients using edible films and coatings. In Edible Films and Coatings for Food Applications; Embuscado, M.E., Huber, K.C., Eds.; Springer: New York, NY, USA, 2009; pp. 295-313.

38. Bautista-Banos, S.; Hernandez-Lauzardo, A.N.; Velazquez-del Valle, M.G.; Hernandez-Lo, M.; Ait Barka, E.; Bosquez-Molina, E.; Wilson, C.L. Chitosan as a potential natural compound to control pre and postharvest diseases of horticultural commodities. Crop. Prot. 2006, 25, 108-118.

39. Jiang, Y.M.; Li, J.R.; Jiang, W.B. Effects of chitosan coating on shelf life of cold stored litchi fruit at ambient temperature. LWT-Food Sci. Technol. 2005, 38, 757-761.

40. Shiekh, R.A.; Malik, M.A.; Al-Thabaiti, S.A.; Shiekh, M.A. Chitosan as a novel edible coating for fresh fruits. Food Sci. Technol. Res. 2013, 19, 139-155.

41. Shahidi, F.; Arachchi, J.K.V.; Jeon, Y. Food application of chitin and chitosan. Trends Food Sci. Tech. 1999, 10, 37-51.

42. Moncayo, D.; Buitrago, G.; Algecira, N. The surface properties of biopolymer-coated fruit: A review. Ing. Invest. 2013, 33, 11-16. 
43. Meng, X.H.; Li, B.Q.; Liu, J.; Tian, S.P. Physiological responses and quality attributes of table grape fruit to chitosan preharvest spray and postharvest coating during storage. Food Chem. 2008, 106, 501-508.

44. Romanazzi, G.; Nigro, F.; Ippolito, A.; di Venere, D.; Salerno, M. Effects of pre- and postharvest chitosan treatments to control storage grey mold of table grapes. J. Food Sci. 2002, 67, 1862-1867.

45. Ziani, K.; Fernandez Pan, I.; Royo, M.; Maté, J. Antifungal activity of films and solutions based on chitosan. Food Hydrocoll. 2009, 23, 2309-2314.

46. Aider, M. Chitosan application for active bio-based films production and potential in the food industry: Review. LWT Food Sci. Technol. 2010, 43, 837-842.

47. Benhabiles, M.S.; Drouiche, N.; Lounici, H.; Pauss, A.; Mameri, N. Effect of shrimp chitosan coatings as affected by chitosan extraction processes on postharvest quality of strawberry. Food Meas. 2013, 7, 215-221.

48. Lou, M.M.; Zhu, B.; Muhammad, I.; Li, B.; Xie, G.L.; Wang, Y.L.; Li, H.Y.; Sun, G.C. Antibacterial activity and mechanism of action of chitosan solutions against apricot fruit rot pathogen Burkholderia seminalis. Carbohydr. Res. 2011, 346, 1294-1301.

49. Liu, L.; Liu, C.K.; Hicks, K.B. Composite films from pectin and fish skin gelatin or soybean flour protein. J. Agric. Food Chem. 2007, 55, 2349-2355.

50. El Ghaouth, A.; Arul, J.; Grenier, J.; Asselin, A. Antifungal activity of chitosan on two post-harvest pathogens of strawberry fruits. Phytopathology 1992, 82, 398-402.

51. Park, S.I.; Stan, S.D.; Daeschel, M.A.; Zhao, Y. Antifungal coatings on fresh strawberries $($ Fragaria $\times$ ananassa) to control mold growth during cold storage. J. Food Sci. 2005, 70, 202-207.

52. Chien, P.J.; Sheu, F.; Lin, H.R. Coating citrus (Murcott tangor) fruit with low molecular weight chitosan increases postharvest quality and shelf life. Food Chem. 2007, 100, 1160-1164.

53. Gonzalez-Aguilar, G.A.; Valenzuela-Soto, E.; Lizardi-Mendoza, J.; Goycoolea, F.; Martinez-Tellez, M.A.; Villegas-Ochoa, M.A.; Monroy-Garcia, I.N.; Ayala-Zavala, J.F. Effect of chitosan coating in preventing deterioration and preserving the quality of fresh-cut papaya "Maradol”. J. Sci. Food Agric. 2009, 89, 15-23.

54. Ali, A.; Muhammad, M.T.M.; Sijam, K.; Siddiqui, Y. Effect of chitosan coatings on the physicochemical characteristics of Eksotika. II papaya (Carica papaya L.) fruit during cold storage. Food Chem. 2011, 124, 620-626.

55. Pilon, L.; Poliana, C.; Spricigo, M.M.; de Moura, M.R.; Assis, O.B.G.; Mattoso, L.H.C.; Ferreira, M.D. Chitosan nanoparticle coatings reduce microbial growth on fresh-cut apples while not affecting quality attributes. Int. J. Food Sci. Technol. 2015, 50, 440-444.

56. Benhabiles, M.S.; Tazdait, D.; Abdi, N.; Lounici, H.; Drouiche, N.; Goosen, M.F.A.; Mameri, N. Assessment of coating tomato fruit with shrimp shell chitosan and N,O-carboxymethyl chitosan on postharvest preservation. Food Meas. 2013, 7, 66-74.

57. Assis, O.B.; Pessoa, J.D. Preparation of thin films of chitosan for use as edible coatings to inhibit fungal growth on sliced fruits. Braz. J. Food Technol. 2004, 7, 7-22.

58. Han, C.; Lederer, C.; McDaniel, M.; Zhao, Y. Sensory evaluation of fresh strawberries (Fragaria ananassa) coated with chitosan-based edible coatings. J. Food Sci. 2005, 70, S172-S178. 
59. Durango, A.M.; Soares, N.F.F.; Andrade, N.J. Microbiological evaluation of an edible antimicrobial coating on minimally processed carrots. Food Control 2006, 17, 336-341.

60. Devlieghere, F.; Vermeulen, A.; Debevere, J. Chitosan: Antimicrobial activity, interactions with food components and applicability as a coating on fruit and vegetables. Food Microbiol. 2004, 21, $703-714$.

61. Pushkala, R.; Raghuram, P.K.; Srividya, N. Chitosan based powder coating technique to enhance phytochemicals and shelf life quality of radish shreds. Postharvest Biol. Tec. 2013, 86, 402-408.

62. Jianglian, D.; Shaoying, Z. Application of chitosan based coating in fruit and vegetable preservation: A review. J. Food Process. Technol. 2013, 4, 227:1-227:4.

63. Yu, Y.W.; Li, H.; Jinhua, D.; Ren, Y.Z. Study of natural film with chitosan combining phytic acids on preservation of fresh-cutting lotus root. J. Chin. Inst. Food Sci. Technol. 2012, 12, 131-136.

64. Cong, F.; Zhang, Y.; Dong, W. Use of surface coatings with natamycin to improve the storability of Hami melon at ambient temperature. Postharvest Biol. Technol. 2007, 46, 71-75.

65. Zhang, H.; Li, R.; Liu W. Effects of chitin and its derivative chitosan on postharvest decay of fruits: A Review. Int. J. Mol. Sci. 2011, 12, 917-934.

66. Salgado, P.R.; Ortiz, C.M.; Musso, Y.S.; di Giorgio, L.; Mauri, A.N. Edible films and coatings containing bioactives. Curr. Opin. Food Sci. 2015, 5, 86-92.

67. Speranza, B.; Corbo, M.R. Essential Oils for Preserving Perishable Foods: Possibilities and Limitations. In Application of Alternative Food Preservation Technologies to Enhance Food Safety and Stability; Bevilacqua, A., Corbo, M.R., Sinigaglia, M., Eds.; Bentham Publisher: Saif Zone, Sharjah, 2010; pp. 35-57.

68. Patrignani, F.; Siroli, L.; Serrazanetti, D.I.; Gardini, F.; Lanciotti, R. Innovative strategies based on the use of essential oils and their components to improve safety, shelf-life and quality of minimally processed fruits and vegetables. Trends Food Sci. Technol. 2015, doi:10.1016/ j.tifs.2015.03.009.

69. Sánchez-González, L.; Cháfer, M.; Hernández, M.; Chiralt, A.; González-Martínez, C. Antimicrobial activity of polysaccharide films containing essential oils. Food Control. 2011, 22, 1302-1310.

70. Xing, Y.; Li, X.; Xu, Q.; Yun, J.; Lu, Y.; Tang, Y. Effects of chitosan coating enriched with cinnamon oil on qualitative properties of sweet pepper (Capsicum annuum L.). Food Chem. 2011, $124,1443-1450$.

71. Sessa, M.; Ferraria, G.; Donsib, F. Novel edible coating containing Essential Oil nanoemulsions to prolong the shelf life of vegetable products. Chem. Eng. Trans. 2015, doi:10.3303/CET1543010.

72. Randazzo, W.; Jimenez-Belenguer, A.; Settanni, L.; Perdones, A.; Moschetti, M.; Palazzolo, E.; Guarrasi, V.; Vargas, M.; Germanà, M.A.; Moschetti, G. Antilisterial effect of citrus essential oils and their performance in edible film formulations. Food Control. 2016, 59, 750-758.

73. Sangsuwan, J.; Rattanapanone, N.; Rachtanapun, P. Effect of chitosan/methyl cellulose films on microbial and quality characteristics of fresh-cut cantaloupe and pineapple. Postharvest Biol. Technol. 2008, 49, 403-410.

74. Krasaekoopt, W.; Mabumrung, J. Microbiological evaluation of edible coated fresh-cut cantaloupe. Kasetsart. J. Nat. Sci. 2008, 42, 552-557. 
75. Corbo, M.R.; Speranza, B.; Campaniello, D.; D’Amato, D.; Sinigaglia, M. Fresh-cut fruits preservation: Current status and emerging technologies. In Current Research, Technology and Education topics in Applied Microbiology; Mendez-Villas, A., Ed.; Formatex Research Center: Badajoz, Spain, 2011; pp. 1143-1154.

76. Corbo, M.R.; Bevilacqua, A. Alternative Modified Atmosphere for Fresh Food Packaging. In Application of Alternative Food Preservation Technologies to Enhance Food Safety and Stability; Bevilacqua, A., Corbo, M.R., Sinigaglia, M., Eds.; Bentham Publisher: Saif Zone, Sharjah, 2010; pp. 196-204.

77. Siddiqui, M.W.; Chakraborty, I.; Ayala-Zavala, J.F.; Dhua, R.S. Advances in minimal processing of fruits and vegetables: A review. J. Sci. Ind. Res. 2011, 70, 823-834.

78. Church, N. Developments in modified-atmosphere packaging and related technologies. Trends Food Sci. Technol. 1994, 5, 345-352.

79. Farber, J.M. Microbiological Aspects of Modified-Atmosphere Packaging Technology-A Review. J. Food Protect. 1991, 54, 58-70.

80. Phillips, C.A. Review: Modified Atmosphere Packaging and Its Effects on the Microbiological Quality and Safety of Produce. Int. J. Food Sci. Technol. 1996, 31, 463-479.

81. Church, I.J.; Parsons, A.L. Modified atmosphere packaging technology: A Review. J. Sci. Food Agric. 1995, 67, 143-152.

82. Corbo, M.R.; Lanciotti, R.; Gardini, F.; Sinigaglia, M.; Guerzoni, M.E. Effects of hexanal, (E)-2-hexenal, and storage temperature on shelf life of fresh sliced apples. J. Agric. Food Chem. 2000, 48, 2401-2408.

83. Lanciotti, R.; Gianotti, A.; Patrignani, F.; Belletti, N.; Guerzoni, M.E.; Gardini, F. Use of natural aroma compounds to improve shelf-life and safety of minimally processed fruits. Trends Food Sci. Technol. 2004, 15, 201-208.

84. Campaniello, D.; D'Amato, D.; Corbo, M.R.; Sinigaglia, M. Combined action of hexanal and MAP on minimally processed cactus pear fruit. Int. J. Food Sci. 2005, 1-10.

85. Siroli, L.; Patrignani, F.; Serrazanetti, D.I.; Tabanelli, G.; Montanari, C.; Tappi, S.; Rocculi, P.; Gardini, F.; Lanciotti, R. Efficacy of natural antimicrobials to prolong the shelf-life of minimally processed apples packaged in modified atmosphere. Food Control. 2014, 46, 403-411.

86. Fisher, K.; Phillips, C.; McWatt, L. The use of an antimicrobial citrus vapour to reduce Enterococcus sp. on salad products. Int. J. Food Sci. Technol. 2009, 44, 1748-1754.

87. Tian, J.; Ban, X.; Zeng, H.; He, J.; Huang, B.; Wang, Y. Chemical composition and antifungal activity of essential oil from Cicuta virosa L. var. latisecta Celak. Int. J. Food Microbiol. 2011, $145,464-470$.

88. Vitoratos, A.; Bilalis, D.; Karkanis, A.; Efthimiadou, A. Antifungal Activity of Plant Essential Oils against Botrytis cinerea, Penicillium italicum and Penicillium digitatum. Not. Bot. Horti Agrobot. 2013, 41, 86-92.

89. Chunyang, H.; Xiqing, Y.; Fei, L.; Binxin, S. Effect of High Oxygen Modified Atmosphere Packaging on Fresh-Cut Onion Quality. In Proceedings of the 17th IAPRI World Conference on Packaging, Tianjin, China, 12-15 October 2010. 
90. Jacxsens, L.; Devlieghere, F.; Van der Steen, C.; Debevere, J. Effect of high oxygen modified atmosphere packaging on microbial growth and sensorial qualities of fresh-cut produce Int. J. Food Microbiol. 2001, 71, 197-210.

91. Day, B.P.F. New modified atmosphere techniques fresh prepared fruit and vegetables. In Fruit and Vegetables Processing; Jongen, W., Ed.; Woodhead Publishing Limited, Cambridge, UK, 2002; pp. 310-330.

92. Amanatidou, A.; Smid, E.J.; Gorris, L.G.M. Effect of elevated oxygen and carbon dioxide on the surface growth of vegetable-associated micro-organisms J. Appl. Microbiol. 1999, 86, 429-438.

93. Kader, A.; Ben-Yehoshua, S. Effects of superatmospheric oxygen levels on postharvest physiology and quality of fresh fruits and vegetables. Postharvest Biol. Technol. 2000, 20, 1-13.

94. Allende, A.; Jacxsens, L.; Devlieghere, F.; Debevere, J.; Artés, F. Effect of Superatmospheric Oxygen Packaging on Sensorial Quality, Spoilage, and Listeria monocytogenes and Aeromonas caviae Growth in Fresh Processed Mixed Salads J. Food Protect. 2002, 65, 1565-1573.

95. Senesi, E.; De Regibus, P. Use of rectified apple juice as filling liquid to increase quality and shelf-life of fresh-cut apples (Succo di mela rettificato come liquido di governo per prolungare la curabilita' di spicchi di mela di IV gamma). Ind. Aliment. 2002, 41, 139-146.

96. D'Amato, D.; Sinigaglia, M.; Corbo, M.R. Use of chitosan, honey and pineapple juice as filling liquids for increasing the microbiological shelf life of a fruit-based salad. Int. J. Food Sci. Technol. 2010, 45, 1033-1041.

97. Galvez, A.; Abriouel, H.; Benomar, N.; Lucas, R. Microbial antagonists to food-borne pathogens and biocontrol. Curr. Opin. Biotechnol. 2010, 21, 142-148.

98. Vermeiren, L.; Devlieghere, F.; Debevere, J. Evaluation of meat born lactic acid bacteria as protective cultures for the biopreservation of cooked meat products. Int. J. Food Microbiol. 2004, 96, 149-164.

99. Siroli, L.; Patrignani, F.; Serrazanetti, D.I.; Tabanelli, G.; Montanari, C.; Gardini, F. Lanciotti, R. Lactic acid bacteria and natural antimicrobials to improve the safety and shelf-life of minimally processed sliced apples and lamb's lettuce. Food Microbiol. 2015, 47, 74-84.

100. Carr, F.J.; Chill, D.; Maida, N. The lactic acid bacteria: A literature survey. Crit. Rev. Microbiol. 2002, 28, 281-370.

101. Abadias, M.; Usall, J.; Alegre, I.; Torres, R.; Vinas, I. Fate of Escherichia coli in apple and reduction of its growth using the postharvest biocontrol agent Candida Sake CPA-1. J. Sci. Food Agric. 2009, 89, 1526-1533.

102. Alegre, I.; Vinas, I.; Usall, J.; Anguera, M.; Altisent, R.; Abadias, M. Antagonistic effect of Pseudomonas graminis CPA-7 against foodborne pathogens in fresh-cut apples under simulated commercial conditions. Food Microbiol. 2013, 33, 139-148.

103. Trias, R.; Badosa, E.; Montesinos, E.; Baneras, L. Bioprotective Leuconostoc strains against Listeria monocytogenes in fresh fruits and vegetables. Int. Microbiol. 2008, 127, 91-98.

104. Trias, R.; Baneras, L.; Badosa, E.; Montesinos, E. Bioprotection of Golden Delicious apples and Iceberg lettuce against foodborne bacterial pathogens by lactic acid bacteria. Int. J. Food Microbiol. 2008, 123, 50-60. 
105. Alegre, I.; Vinas, I.; Usall, J.; Anguera, M.; Figge, M.J.; Abadias, M. Control of foodborne pathogens on fresh-cut fruit by a novel strain of Pseudomonas graminis. Food Microbiol. 2013, 34, 390-399.

106. Leverentz, B.; Conway, W.S.; Janisiewicz, W.; Abadias, M.; Kurtzman, C.P.; Camp, M.J. Biocontrol of the food-borne pathogens Listeria monocytogenes and Salmonella Enterica serovar poona on fresh-cut apples with naturally occurring bacterial and yeast antagonists. Appl. Environ. Microb. 2006, 72, 1135-1140.

107. Alegre, I.; Vinas, I.; Usall, J.; Anguera, M.; Figge, M.J.; Abadias, M. An Enterobacteriaceae species isolated from apples controls foodborne pathogens on fresh-cut apples and peaches. Postharvest Biol. Technol. 2012, 74, 118-124.

108. Siroli, L.; Patrignani, F.; Salvetti, E.; Torriani, S.; Gardini, F.; Lanciotti, R. Use of a nisin-producing Lactococcus lactis strain, combined with thyme essential oil, to improve the safety and shelf-life of minimally processed lamb's lettuce. In Proceeding of the 11th International Symposium on lactic acid bacteria, Egmond aan Zee, The Netherlands, 31 August-4 September 2014.

109. Abadias, M.; Altisent, R.; Usall, J.; Torres, R.; Oliveira, M.; Vinas, I. Biopreservation of fresh-cut melon using the strain Pseudomonas graminis CPA-7. Postharvest Biol. Technol. 2014, 96, 69-77.

110. Plaza, L.; Altisent, R.; Alegre, I.; Vinas, I.; Abadias, M. Changes in the quality and antioxidant properties of fresh-cut melon treated with the biopreservative culture Pseudomonas graminis CPA-7 during refrigerated storage. Postharvest Biol. Technol. 2016, 111, 25-30.

111. Scolari, G.; Vescovo, M. Microbial antagonism of Lactobacillus casei added to fresh vegetables. Int. J. Food Sci. 2004, 16, 465-475.

112. Rößle, C.; Auty, M.A.E.; Brunton, N.; Gormley, R.T.; Butler, F. Evaluation of fresh-cut apple slices enriched with probiotic bacteria. Innov. Food Sci. Emerg. 2010, 11, 203-209.

113. Alegre, I.; Viñas, I.; Usall, J.; Anguera, M.; Abadias, M. Microbiological and physicochemical quality of fresh-cut apple enriched with the probiotic strain Lactobacillus rhamnosus GG. Food Microbiol. 2011, 28, 59-66.

114. Tapia, M.S.; Rojas-Graü, M.A.; Rodríguez, F.J.; Ramirez, J.; Carmona, A.; Martín-Belloso, O. Alginate and Gellan-based edible films for probiotic coatings on fresh-cut fruits. J. Food Sci. 2007, 72, 190-196.

115. Cleveland, J.; Montville, T.J.; Nes, I.F.; Chikindas, M.L. Bacteriocins: Safe, natural antimicrobials for food preservation. Int. J. Food Microbiol. 2001, 71, 1-20.

116. Allende, A.; Martınez, B.; Selma, V.; Gil, M.I.; Suarez, J.E.; Rodrıguez, A. Growth and bacteriocin production by lactic acid bacteria in vegetable broth and their effectiveness at reducing Listeria monocytogenes in vitro and in fresh-cut lettuce. Food Microbiol. 2007, 24, 759-766.

117. Randazzo, C.L.; Pitino, I.; Scifo, G.O.; Caggia, C. Biopreservation of minimally processed iceberg lettuces using a bacteriocin produced by Lactococcus lactis wild strain. Food Control. 2009, 20, 756-763.

118. Schuenzel, K.M.; Harrison, M.A. Microbial antagonists of foodborne pathogens on fresh, minimally processed vegetables. J. Food Protect. 2002, 65, 1909-1915. 
119. Scolari, G.; Vescovo, M.; Zacconi, C.; Bonade, A. Influence of Lactobacillus plantarum on Staphylococcus aureus growth in a fresh vegetable model system. Eur. Food Res. Technol. 2004, 218, 274-277.

120. Rojas-Graü, M.A.; Sobrino-López, A.; Tapia, M.S.; Martín-Belloso, O. Browning inhibition in fresh-cut Fuji apple slices by natural antibrowning agents. J. Food Sci. 2006, 71, 59-65.

121. Soccol, C.R.; Vandenberghe, L.P.S.; Spier, M.R.; Medeiros, A.B.P.; Yamaguishi, C.T.; Lindner, J.D., Pandey, A.; Soccol, V.T. The potential of probiotics. Food Tech. Biotechnol. 2010, 48, 413-434.

122. Kourkoutas, Y.; Kanellaki, M.; Koutinas, A.A. Apple pieces as immobilization support of various microorganisms. LWT-Food Sci. Technol. 2006, 39, 980-986.

123. Shah, N.P. Functional cultures and health benefits. Int. Dairy J. 2007, 17, 1262-1277.

124. Kailasapathy, K. Microencapsulation of probiotic bacteria: Technology and potential application. Curr. Issues Intest. Microbiol. 2002, 3, 39-49.

125. Guerin, D.; Vuillemard, J.C.; Subirade, M. Protection of Bifidobacteria encapsulated in polysaccharide-protein gel beads against gastric juice and bile. J. Food Protect. 2003, 66, 2076-2084.

126. Kourkoutas, Y.; Xolias, V.; Kallis, M.; Bezirtzoglou, E.; Kanellaki, M. Lactobacillus casei cell immobilization on fruit pieces for probiotic additive, fermented milk and lactic acid production. Process. Biochem. 2005, 40, 411-416.

127. Saad, S.M.I.; Bedani, R.; Mamizuka, E.M. Benefícios à Saude dos Probióticos e Prebióticos. In Probióticos e Prebióticos em Alimentos: Fundamentos e Aplicações Tecnológicas; Saad, S.M.I., Cruz, A.G., Faria, J.A.F., Eds.; Editora Varela: São Paulo, Brazil, 2011; pp. 51-84. In Portuguese.

(C) 2015 by the authors; licensee MDPI, Basel, Switzerland. This article is an open access article distributed under the terms and conditions of the Creative Commons Attribution license (http://creativecommons.org/licenses/by/4.0/). 